\title{
Functionalization of Ceramic Coatings for Enhancing Integration in Osteoporotic Bone: A Systematic Review
}

\author{
Maria Sartori ${ }^{1}{ }^{1}$, Melania Maglio ${ }^{1, *}$, Matilde Tschon ${ }^{1}$, Nicolò Nicoli Aldini ${ }^{1}$, Andrea Visani ${ }^{2}$ \\ and Milena Fini ${ }^{2}$ \\ 1 Laboratory of Preclinical and Surgical Studies, IRCCS—Istituto Ortopedico Rizzoli, via di Barbiano 1/10, \\ 40136 Bologna, Italy; maria.sartori@ior.it (M.S.); matilde.tschon@ior.it (M.T.); \\ nicolo.nicolialdini@ior.it (N.N.A.) \\ 2 Laboratory of Biomechanic and Innovative Technology, IRCCS-Istituto Ortopedico Rizzoli, \\ via di Barbiano 1/10, 40136 Bologna, Italy; andrea.visani@ior.it (A.V.); milena.fini@ior.it (M.F.) \\ * Correspondence: melania.maglio@ior.it; Tel.: +39-051-636-6006
}

Received: 11 April 2019; Accepted: 6 May 2019; Published: 9 May 2019

\begin{abstract}
Background: The success of reconstructive orthopaedic surgery strongly depends on the mechanical and biological integration between the prosthesis and the host bone tissue. Progressive population ageing with increased frequency of altered bone metabolism conditions requires new strategies for ensuring an early implant fixation and long-term stability. Ceramic materials and ceramic-based coatings, owing to the release of calcium phosphate and to the precipitation of a biological apatite at the bone-implant interface, are able to promote a strong bonding between the host bone and the implant. Methods: The aim of the present systematic review is the analysis of the existing literature on the functionalization strategies for improving the implant osteointegration in osteoporotic bone and their relative translation into the clinical practice. The review process, conducted on two electronic databases, identified 47 eligible preclinical studies and 5 clinical trials. Results: Preclinical data analysis showed that functionalization with both organic and inorganic molecules usually improves osseointegration in the osteoporotic condition, assessed mainly in rodent models. Clinical studies, mainly retrospective, have tested no functionalization strategies. Registered trademarks materials have been investigated and there is lack of information about the micro- or nano- topography of ceramics. Conclusions: Ceramic materials/coatings functionalization obtained promising results in improving implant osseointegration even in osteoporotic conditions but preclinical evidence has not been fully translated to clinical applications.
\end{abstract}

Keywords: coatings; ceramic materials; functionalization; osteointegration; osteoporosis; bone metabolism; animal model

\section{Introduction}

In the twenty-first century, performing an implant procedure, ranging from screw insertion to total joint replacement, has become practically "routine" in orthopaedics and traumatology as well as in dentistry. Besides the surgical technique, other several factors are involved in determining the success of the implant, not just as a procedure but as a final outcome in term of osteointegration. Osteointegration is a biological concept that develops as a multistage process in which different cell/tissue events, reparative/regenerative mechanisms and local and systemic factors concur to the integration of a foreign body into the host bone [1,2].

The biomaterial surface properties, as surface energy, chemical composition, geometry, topography, wettability, roughness represent crucial players involved in the establishment of an optimal bone/implant 
interface and capable of influencing the type of interaction between biomaterials and biological environment. Over the years, the in-depth research and analysis of biomaterials properties has led to the understanding that functionalizing biomaterials can represent a winning strategy in determining the success of the osteointegration process [3]. To functionalize means to modify the biomaterial surface properties conferring new functionalities in order to achieve specific goals. Through the functionalization, the applicability of the original biomaterial is further broadened to serve specific purposes [4].

Physical, chemical and biological functionalizations represent the available strategies for tailoring a material's surface based on the technique or surface modifier taken into consideration. Physical functionalization is performed to improve the topographical properties of biomaterials, the pore size and the morphology in order to act onto cell differentiation, migration and adhesion. Chemical functionalization is pursued to modify composition, energy or surface charge to direct and influence cells interaction and adhesion. Finally, biological functionalization is performed with covalent or non-covalent immobilization or conjugation of biomolecules, drugs, growth factors and peptides, which can elicit a specific biological response directing cell behaviours or inhibiting adverse reactions $[4,5]$.

A good quality of bone bed certainly represents a positive prognostic factor for the osteointegrative process; however, quite often orthopaedics are faced with patients whose bone status is compromised by systemic diseases or disorders, such as osteoporosis or diabetes, immunologic pathologies, oncologic diseases requiring anticancer therapies or various other age and lifestyle-related pathological conditions [6-8].

Osteoporosis (OP) is one of the most common musculoskeletal disorders in which low bone mass and bone micro-architecture and extra-cellular matrix (ECM) impairment leads to an increase of fracture susceptibility [9].

According to recent epidemiologic data, the growing prevalence of $\mathrm{OP}$, also due to the increase in life expectancy, has led to a higher incidence of fragility fracture, experienced by $44 \%$ of women and $25 \%$ of men $[10,11]$.

Although from a clinical perspective, $\mathrm{OP}$ is not considered a contraindication for implant placement [12], several experimental data report that OP may jeopardize bone healing and regeneration, thus reducing osteointegration and worsen the support provided by the host bone [13].

That is why many research studies focus on the development of smart biomaterials with improved features aimed at enhancing osteointegration and implant primary and biological stability. In very challenging situations of poor bone quality and quantity, such as in OP, ceramics, as bulk material or coating, seem to be the most promising choice to promote bone regeneration processes improving bone healing and osteointegration $[14,15]$. In fact, the results of a recently published review and meta-analysis of preclinical research on osteointegration in osteoporotic conditions highlighted that ceramics, and in particular calcium phosphate ( $\mathrm{CaP})$, improve one of the main histological osteointegration parameters (i.e., bone to implant contact-BIC), in comparison with uncoated implants [16]. It has been widely demonstrated that $\mathrm{CaP}$ materials are able to favour bone regeneration due to biological affinity with bone tissue: thanks to a dissolution process, the increasing $\mathrm{Ca}$ and $\mathrm{P}$ ion concentration in the local microenvironment significantly improves the adhesion of osteoblast-like cells and mesenchymal stem cells on implant surfaces. The subsequent precipitation of a biological apatite with a composition similar to bone serves as a matrix for cell attachment and growth. Concurrently, osteoclasts (OCs) are actively involved in the dissolution process of biological apatite, thus favouring new bone growth into fissures and defects left by the resorbing process in the post-operative period [17-19].

In light of these aspects, the attention has now been focused on the use of functionalized ceramic materials used both as synthetic bone graft substitutes than as a thin coating on metallic implants with the aim to further improve the biological properties of biomaterials thus favouring and improving fixation and osteointegration, especially in OP bone. The functionalization strategies performed both through the enrichment of the bulk ceramic material with trace ionic species or drugs as well as with biological 
entities as growth factors, drugs, peptides or cells, have emerged as a very promising alternative to induce cellular response and further stimulate endogenous reparative/regenerative mechanisms.

Therefore, the aim of this study is to systematically review the preclinical and clinical literature on the subject of bone osteointegration in osteoporotic conditions. Since the effect of ceramic materials on osteointegrative processes in osteoporosis has been already demonstrated [16], the present review aims to provide a view on the state of the art on the functionalization strategies of ceramic materials or coatings and their effects on the osteointegration process in osteoporotic conditions also assessing which of these approaches have been or can be translated to the clinical application.

\section{Methods}

\subsection{Focused Question}

A focused question was formulated according to the preferred reporting items for systematic reviews and meta-analyses (PRISMA) [20]. A specific question was formulated according to the participants, interventions, control and outcomes (PICO) principle. The focused question was 'What are the main effects of ceramic functionalization strategies on osteointegration in OP conditions?' (P) Participants: It was essential for the animals/patients to have an implant placement. (I) Types of interventions: The intervention of interest was the evaluation of ceramic functionalization strategies onto osteointegration in OP condition. (C) Control Intervention: Osteointegration without functionalization strategies. (O) Outcome Measures: Main functional scores, histomorphometric, radiological and mechanical parameters related to osteointegration.

\subsection{Descriptive Systematic Literature Review}

This systematic review was carried out according to the PRISMA guidelines. Electronic database searches were performed on www.pubmed.com and www.webofknowledge.com to identify studies reporting the following key terms: "(osteointegration OR osseointegration OR bone implant OR bone prosthesis) AND (osteoporosis OR osteopenia) AND (ceramics OR hydroxyapatite OR calcium phosphate OR calcium sulphate)." Study eligibility was independently determined by reviewing titles and abstracts using the following inclusion criteria: preclinical and clinical studies of any level of evidence, full text, English language, reports published from January 2011 to January 2019. Exclusion criteria were articles not in English, reviews and meta-analysis, in vitro studies and papers with no ceramic materials or no osteoporosis/osteopenia as reported in Figure 1. Any study failing to meet eligibility after full-text review was excluded and references from each full-text article were reviewed for inclusion eligibility. The screening process was conducted separately by two independent researchers (M.S. and M.T.). Disagreements were resolved by discussion: where a resolution was not possible, a third reviewer (M.M.) was consulted.

\subsection{Data Extraction and Management}

General characteristics were extracted from preclinical studies (M.S. and M.M.), including the adopted animal model, number of animals and site of implant, material characteristics and type of functionalization, experimental set up and main results. From clinical studies, enrolled patients and treated pathology, type of trial, anatomical site and type of prosthesis, aims, patient groups and the analysed patient number, quantitative measurements and main results were extracted (M.T.). 


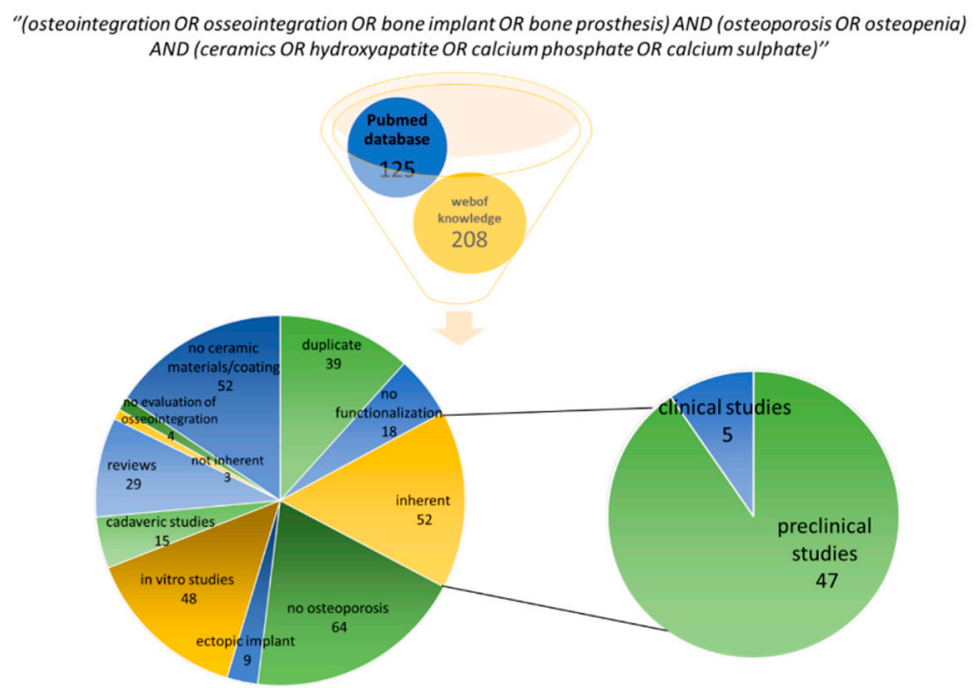

Figure 1. Flowchart of the research strategy.

\section{Results}

\subsection{Summary of the Literature Results}

The a priori search retrieved 125 articles from www.pubmed.com and 208 from www.webofscience. com. After screening, several articles (242) were excluded: 51 studies did not evaluate ceramic materials or ceramic coatings; in 64 studies the osteoporotic or osteopenic condition was not present; 48 studies were in vitro; in 9 studies an ectopic implant was performed; 29 were reviews; 15 cadaveric studies; 3 studies were not related to the topic of the present review and in other 4 studies no analysis related to osteointegration has been performed. Finally, in 19 studies, no functionalizations of ceramic material or coating were performed. Therefore, a total of 91 papers were recognized as eligible for the review and after the use of a public reference manager (Mendeley 1.19.3) to eliminate duplicate articles, 52 papers have been evaluated: 47 preclinical studies and 5 clinical studies (Figure 1). The results of the research were reported stratifying the preclinical papers according to small, medium and large animal models and clinical studies.

\subsection{Preclinical Studies}

Preclinical studies were evaluated considering (i) the animal model and the strategy adopted to induce OP or osteopenia; (ii) type of surgery and site of implant; (iii) the main characteristics of ceramic material/coating and the type of functionalization; (iv) the experimental set-up (study groups, experimental times and analyses) and (v) the main results obtained on osteointegration. Out of 47 preclinical studies, 31 were conducted in small animal models, 8 in medium sized animal models and 8 in large sized animal models. All studies were conducted in osteoporotic animal models.

\subsubsection{Small Animal Models}

Rodents are the most used preclinical model for the evaluation of implant coatings in OP. A single study employed a mouse model, while 30 rats were employed in the others. In all studies, OP was established via bilateral ovariectomy, in 4 studies also combined with low calcium diet. In the mouse study a genetic model was created. Only one study employed male rats. In the mouse study, a composite material of ceramic and bioglass, with and without brain-derived neurotrophic factor (BDNF), was implanted in femurs.

As for the rat model, 20/30 implant sites were femur, 6/30 were tibia, 3/30 were calvaria and one study was in the mandible. Among femoral implantation, in 8/20 studies, materials were placed in the medullary cavity. In 17/30 studies, the implanted material was ceramic, 12 were titanium 
(Ti) implants while in one study, both ceramics and different hydrogels compositions were used. Regarding functionalizations, 3 studies used bisphosphonate (BPs), 1 melatonin (Mel), 1 lithium (Li), 1 icariin, 1 simvastatin (SIM), 16 trace elements (TE), 1 bone marrow stromal cells (BMSCs), 1 bone morphogenetic protein-2 (BMP-2), 2 poly(lactic-co-glycolic acid) (PLGA), 1 poly(ethylene glycol) (PEG), 1 combined BPs and TE and another 1 PLGA and TE (Table A1 in Appendix A).

\section{Mouse Model}

Kauschke et al. [21] created a genetic model of OP to investigate the effect on bone regeneration of $\alpha$-tricalcium phosphate $(\alpha-\mathrm{TCP})$-based hydroxyapatite (HA) containing bioactive CaP-silicon dioxide $\left(\mathrm{SiO}_{2}\right)$ glass particles with or without BDNF functionalization. The outcomes of implantation in the distal femoral metaphyseal gap highlighted a greater regenerative potential in the healthy group than in OP ones. The authors suggest that a higher concentration of BDNF should be needed in order to observe effects also in the osteoporotic condition.

\section{Rat Model}

Almost one half of the included articles (15/30) investigated the performance of Ti implants coated or combined with different materials/adjuvant in OP rats. Alghamadi et al. [22] investigated a CaP coating functionalized with alendronate (ALN), assessing that the simultaneous release of $\mathrm{CaP}$ and BPs act positively both on bone formation and on the rate of bone resorption in comparison to CaP or BPs single coatings also in OP. Pyo SW et al. also investigated CaP coatings with the addition of zoledronate (ZOL) at different concentration (from 0 to $800 \mu \mathrm{g} / \mathrm{mL}$ ), immobilized on Ti screws [23]. In this case, at the highest ZOL concentration corresponded the best result in terms of bone growth in both healthy and OP, while BIC values were found lower in comparison to the control group. No data of ZOL release from CaP coating around the implants have been reported. Kettenberg et al. instead filled the holes of a metallic screw with a hyaluronan derivative hydrogel containing HA and ZOL. Their findings showed that the hydrogel acted as carriers but at the same was mineralized by the presence of HA; ZOL prevented hydrogel resorption, thus promoting bone regeneration [24].

The group by $\mathrm{Li}$ et al. examined in different researches the loading of traced elements, as strontium $(\mathrm{Sr})$, magnesium $(\mathrm{Mg})$ or zinc $(\mathrm{Zn})$, onto HA coating of Ti materials implanted in femurs. The HA coating functionalization with $\mathrm{Mg}$ or $\mathrm{Zn}$ was proven to improve maximum push out force and BIC values, suggesting a better osteointegration in comparison with HA alone $[25,26]$; similar results were obtained with $10 \%$ SrHA coating, which proved to have a trophic effects on the trabecular architecture of bone around implants, increasing bone density and bone formation [27]. In light of this result, the effectiveness of the $10 \%$ SrHA coating was tested after treatment with subcutaneous injection of ZOL, to mimic clinical situations of patients undergoing systemic BPs therapy, showing good outcomes in terms of bone density and the main microtomographical trabecular parameters [28].

Tao et al. also adopted $\mathrm{Sr}$ coating to improve the osteointegration of Ti and ceramic materials in OP and osteopenic rats. The work group identified a direct correlation between the percentage of Sr ions used for coating (range tested: 5\%-20\%) and implant osseointegration measured by microtomography, histology and mechanical tests [29]. Although experimental coating with $\mathrm{Mg}$ and $\mathrm{Zn}$ showed good results in terms of implant integration and fixation and bone formation, the group treated with $10 \%$ Sr coating had significantly higher values of tested parameters [30]. Zhang et al. set up an analogue experimental model testing lower percentage of the same ions (2.5\% of Mg, $\mathrm{Zn}$ and Sr) [31]. Even in these cases the addition of trace elements did not alter HA implant porosity and general morphology, while the best results in terms of bone density and BIC values were obtained in presence of Sr and Zn, in comparison to $\mathrm{Mg}$ or $\mathrm{HA}$ alone. Furthermore, the addition of $\mathrm{Si}, \mathrm{Zn}$ and $\mathrm{Sr}$ to ceramic materials proved to be effective not only in improving implant osseointegration in osteoporotic environment but also in reducing bone loss and thus showing a potential therapeutic application for the pathology itself [32]. 
Tao et al. evaluated if the administration of drugs, in this case parathormone (PTH) injected 3 times/weeks subcutaneously at $60 \mathrm{mg} / \mathrm{kg}$, could further improve the performance of $10 \%$ Sr-HA coated Ti implant in promoting bone formation. Results confirmed the hypothesis, showing higher bone formation in the group treated with PTH not only at the interface with implants but also in the medullary cavity in which implant was placed [33]. On this path, the same group tested Sr coating on calcium phosphate cement (CPC) paste and observed that the concurrent administration of BMP improved osteoinductive and osteoconductive processes, both histologically and biomechanically [34].

Moreover, for ceramic materials, the combination with Sr ions led to the most promising results. Baier et al. performing morphological analysis on the materials, observed a less homogenous material profile in Sr-containing calcium phosphate cement (CPC), which seemed to promote bone ingrowth locally around the implants but no systemic effects driven by Sr presence were evidenced with bone mineral density (BMD) evaluation [35]. Cardemil et al. highlighted that $\mathrm{Sr} / \mathrm{CaP}$ granules and HA granules both induce quantitatively comparable healing of trabecular bone defects, driven by different mechanisms [36]. Histological and histomorphometrical evaluations showed different distribution of newly formed bone, linked to the different rate and timing of material resorption. Sr group exhibited higher expression of osteoblastic genes and reduced presence of osteoclastic activity in comparison with the control group [36].

Results obtained from the evaluation of osteogenic potential of Sr incorporated HA micro-granules are in line with these evidences. Chandran et al. demonstrated in a long-term OP-induced aged model that the combination of $\mathrm{Sr}$ and highly porous HA promotes complete bone healing, showing a regeneration efficacy higher than the HA group, also confirmed by microCT evaluation of the trabecular bone status [37].

Thorman et al., in a similar in vivo model, also used time-of-flight secondary ion mass spectrometry (TOF-SIMS) technology to detect ions released from Sr modified CaP cements. The matching between results from TOF-SIMS and evidence from histology and immunohistochemistry (IHC) allowed to attribute the highest bone formation at the interface between SrCPC cement with a high release of $\mathrm{Sr}$ ions from the material, which locally acts promoting bone growth [38].

SrCPC cements were compared with porous scaffold silica/collagen xerogel and monolithic silica/collagen xerogel in a study in which bone formation was assessed with F-18-sodium fluoride (NaF) dynamic PET-CT (dPET-CT). The evaluation of the movement of tracer into and out of the bound bone compartment, reflecting fluorapatite formation, showed the highest values in Sr containing materials, suggesting a greater bone formation in comparison to others and at the same time proposing a different method for studying the efficacy of materials for bone regeneration in OP [39].

Staying in the field of modification of ceramics materials, the group of van Houdt et al. evaluated the performance of CPC (30 wt \%) enriched with PLGA microparticles (70 wt \%). In one study, the degradation rate of CaP/PLGA materials was found to be higher and faster in comparison to Bio-Oss ${ }^{\circledR}$, which instead showed better ability to promote bone formation. The loading of CPC/PLGA $(60-40 \mathrm{wt} \%)$ materials with ALN revealed to be successful in promoting bone formation in comparison to material without pharmaceuticals. The rate of degradation of CPC/PLGA in comparison to CPC alone allowed to control the release of ALN, maximizing the local effect [40].

ALN was also used to synthesize a multifunctional $\mathrm{HA}$, in combination with $\mathrm{Fe}_{3} \mathrm{O}_{4}$, with magnetic properties, which proved to reduce osteoclast activity and promote bone formation via osteoblasts (OBs) activation [41]. The influence of PLGA for osseointegration in OP was also studied by Jeong et al. who combined it with $\beta$-tricalcium phosphate ( $\beta$-TCP) screws, showing that such biocomposite screws increase microtomographical parameter values of bone formation in ovariectomized (OVX) groups [42]. As an alternative to the use of BPs, melatonin was loaded onto a calcium aluminate (CA) scaffold. Melatonin (Mel) proved to act on the overall bone metabolism, balancing bone formation and resorption, promoting bone healing. The addition of platelet rich plasma (PRP) did not exert any trophic effects, probably because of difficulties in selecting the proper administration times, which should consider the different mechanism of actions [43]. Also, doping lithium (Li) onto CPC proved to induce 
early endochondral ossification and new bone formation in comparison to CPC alone, preserving the characteristics of bioactivity and biocompatibility of ceramic materials [44]. While Fang et al. observed that the direct loading of simvastatin (SIM) on implants to substitute systemic administration alter the size of HA crystals, making them smaller and more irregular [45].

One of the most important aspects in bone healing is the onset of adequate angiogenic process. Wu et al. loading CPC cements with icariin, observed a strengthening of both osteogenic and angiogenic phenomena, evaluated with Microfil perfusion analysis, compared to CPC alone [46]. In addition, overall parameters of BMD, serum calcium levels and bone bending strength appeared ameliorated in OVX rats, indicating a systemic, as well as local effect. Xia et al. had the same results locally, evaluating the effect of $\mathrm{Ca}, \mathrm{Mg}$, Si containing akermanite bioceramics, with the best outcome in comparison to $\beta$-TCP alone [47].

Liu W. et al instead focus the attention on the influence that microenvironmental $\mathrm{pH}$ can exert on fracture healing and bone formation in osteoporosis, testing alkaline biodegradable implants. The dosage of this parameter after implantation of $10 \%$ Sr-substituted CA and $\beta$-TCP showed that the presence of the materials induced a rise in $\mathrm{pH}$ level, which correlate with higher bone formation [48].

Liu X. et al., in the only retrieved dental study, seeded rat BMSCs infected with human osteoprotegerin (OPG) adenoviruses in order to express the higher level of the OPG gene onto HA scaffold. Results showed that the construct was able to act on bone homeostasis, promoting new bone formation and regulating resorptive processes, putting itself up as a good candidate for the treatment of bone fracture/defects in condition of compromised bone status [49].

Hauser et al. tested L51P, a BMP-2 variant able to restore BMP2-mediated osteoblasts differentiation inhibiting BMP2 antagonist, in combination with $\beta$-TCP cylinders [50]. To maximize the potentiality of the materials in osteoporotic condition, ALN was subcutaneously injected. The results confirmed that the synergistic effects of BMP2 and L51P augmented bone formation after surgery but on the other hand the reduction in $\beta$-TCP degradation after ALN administration, opened up the question about the concurrence of chemical composition and osteoclasts activity in material resorption.

\subsubsection{Medium Animal Model}

The research retrieved 8 preclinical studies performed on rabbits. In $3 / 8$ studies, OP was induced with bilateral ovariectomy surgery, while in other $3 / 8$, a combination of ovariectomy and corticosteroid administration, mainly methylprednisolone sodium succinate, was used to induce the condition. In the last $2 / 8$ studies, a temporary OP was induced with corticosteroid administration. To evaluate the regenerative potential of ceramic functionalization strategy, in 4/8 studies defects were realized and directly filled with ceramic materials combined with different organic or inorganic molecules, while in $3 / 8$ studies, the functionalization served as a coating for metallic implant. One study investigated a combination of polymeric material screw-shaped and functionalization with Sr. Femur was used as implant site in 6/8 studies, tibia in 1/8 and mandible in 1/8 (Table A2 in Appendix A).

Moreover, in this animal model the use of bisphosphonates recurs. Gong et al. functionalized a calcium silicate powder (CPCS) with $0.5 \%$ risendronate (RA) obtaining an increased bone formation in the defects treated with RA-CPCS $0.5 \%$, in comparison with the ceramic material alone and a preventive effect on bone resorption. In addition, the authors found a significantly up-regulation of several genes related to osteogenesis in comparison to CPCS group [51].

Shen et al. used alendronate to functionalize a coating of hydroxyapatite- $\mathrm{TiO}_{2}$ nanotubes (HA-TNT). In the comparison with experimental groups without functionalization (Ti, TNT and HA-TNT), TNT-HA-ALN coated implants exhibit the greatest regenerative capability in promoting new bone formation around implants as showed by the quantitative results (bone volume/trabecular volume-BV/TV) measured with microtomography [52].

$\mathrm{Wu}$ et al. and Zarins et al. realized a bioactive and bioresorbable screw functionalizing Sr with CPC and then mixing it with poly(e-caprolactone) (PCL). The results showed better performance, in terms of osteointegration, in the Sr-CPC/PCL group with increased values of BV/TV, trabecular 
number (Tb.N), trabecular thickness (Tb.Th) and connectivity density (Conn.Dn) and decrease of Trabecular separation (Tb.Sp) in comparison with the PCL group [53,54].

Zarins et al. investigated the regenerative potential of HA/TCP ceramic granules with or without $5 \%$ strontium observing no statistical difference of bone regeneration among operated and non-operated samples in OP animals. Nevertheless, Sr functionalization increased the expression of different factors related to osteocytes activity as OPG or nuclear factor kappa-light-chain-enhancer of activated B cells (NFkB) [54].

The use of inorganic molecules to impart new functionalities of ceramics is reported by Yu et al. which functionalized CPCS coatings with two different $\mathrm{Zn}$ contents for $\mathrm{Ti}_{6} \mathrm{Al}_{4} \mathrm{~V}$ pin implanted in osteopenic rabbit. The authors observed a significant increase in new bone formation and microarchitectural bone parameters around the implant coated with the higher $\mathrm{Zn}$ content at early (1 month) and late experimental times (3 months) in comparison to the other groups of the study [55].

Among the functionalization performed with biomolecules, the existing papers reported a functionalization of a mesoporous silica with osteostatin or of HA with adiponectin or fibronectin. Lozano et al. adopted the first strategy investigating the recently characterized osteogenic effect of PTHrP epitope (107-111) named osteostatin. Even if no quantitative measurements have been performed in terms of bone regeneration, osteostatin functionalization induced an increased staining for key factors involved in bone regeneration process as proliferating cell nuclear antigen (PCNA), runt-related transcription factor 2 (Runx2), osteopontin (OPN) and vascular endothelial growth factor (VEGF) [56].

Luo et al. and Plaza et al. respectively functionalized HA with adiponectin/matrigel (APN + matrigel) or fibronectin. In the first approach, the authors used matrigel to control the release hormone from HA surface and observed a weaker tartrate-resistant acid phosphatase (TRAP) staining in APN-matrigel-HA group in comparison with the other groups, as well as a significant new bone formation $[57,58]$.

Plaza et al. used fibronectin functionalized HA and coat screw obtaining a significant improvement in trabecular bone microarchitecture parameters, even if not significant in comparison with the HA coating or control [58].

\subsubsection{Large Animal Model}

Eight studies on large animal models (7 sheep and 1 goat) were retrieved from the search strategy. In 6/8 studies OP was induced by bilateral ovariectomy while in $2 / 8$ studies, an osteopenic condition was induced but no indications about the method to induce the condition has been provided. In addition, in 2/8 studies, ovariectomy surgery was also combined with low calcium diet while in other 2/8, a corticosteroid administration was associated with surgery. Finally, in 1/8 studies, ovariectomy surgery, low calcium diet and corticosteroid administration were combined.

The in vivo biological response in terms of osteointegration of functionalization strategies was evaluated realizing confined defects (6/8) in different anatomical regions: in 4/6 at vertebral level, 1/6 in the iliac crest (ALT) and 1/6 in the cortical bone of the thigh. In 2/8 studies, the functionalized ceramic materials were used to coat Ti device implanted in cancellous bone.

The types of functionalization evaluated in large animal models are mainly followed with the use of bioactive biomolecules (6/8). In $1 / 8$ studies the synergistic functionalization of ceramics with organic and inorganic molecules was performed while one study (1/8) adopted BPs as drug to load ceramic material (Table A2 in Appendix A).

In the studies performed by Gunnella et al., the researchers evaluated the regenerative potential of PLGA fibre-reinforced brushite-forming cement (CPC) with BMP-2 or BB-1 at different dosages with augmented bone formation capability. In both of studies, CPC + fibres and/or CPC + fibers + BMP-2 or BB-1 significantly improved the main parameters related to bone formation, resorption and structure in comparison with control, with a dose dependent mechanism $[59,60]$.

James et al. treated lumbar vertebral defects with hyaluronic acid (HyA) combined with $\mathrm{HA} / \beta-\mathrm{TCP}$ further functionalized with rhNELL-1 protein, an osteoinductive factor with both pro-osteogenic and 
anti-osteoclastic properties, in comparison with HA- $\beta$-TCP at two different dosages ( 0.9 and $2.25 \mathrm{mg}$ ). An improved bone quality was detected by microtomographic investigations as BMD significant increase in a dose-dependent manner in defects treated with rhNELL-1 in comparison with control as well as BV/TV and Tb.N showed a significant increase at both dosages. The histomorphometric analysis further confirmed the results obtained with microCT, highlighting an improved cortical and cancellous bone regeneration [61].

A more traditional approach was pursued by Verron et al., who evaluated the performance of a calcium deficient apatite (CDA) functionalized with ALN. In this study, the authors highlighted an improvement in bone content and microarchitectural properties of bone in comparison with CDA alone, within $1.2 \mathrm{~mm}$ from the implant, thus suggesting an anabolic effect distance dependent [62].

In addition, Andreasen et al. evaluated the extension of the effect of its functionalization in terms of distance from the implant site. The authors evaluated the performance of titanium coated with HA/ßTCP functionalized with HyA or reinforced with poly-D,L-lactic acid (PDLLA) in femoral defects in comparison with allograft from healthy sheep. The study takes into consideration, for the quantitative measure, two defined regions of interest (ROIs): ROI- 1 close to the implant and ROI-2 close to the host bone, both having an approximate width of $500 \mu \mathrm{m}$. The two types of functionalizations gave rise to a bone formation and mechanical fixation similar to the allograft group given that no statistically significant difference was observed in BIC parameter comparing allograft with the HA/ $\beta T C P$,

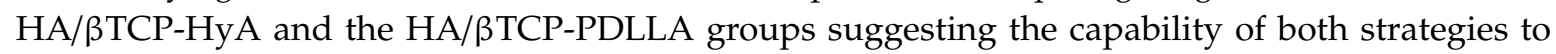
induce bone formation comparably to the allograft [63].

Izquierdo-Barba et al. tested a silicon substituted hydroxyapatite (SiHA) functionalized with VEGF to coat a macroporous titanium implant, observing an higher extent of bone formation in TiSiHA-VEGF group in comparison with the other group (TiSiHA, Ti-VEGF or Ti scaffolds) suggesting that the combination of osteoconductive properties of hydroxyapatite with silica and its biochemical cue and angiogenetic properties sustained by VEGF were able to stimulate bone regeneration [64].

Other two innovative approaches have been found: the route followed by Alt et al., which used a nanoHA also functionalized with collagen type I (col-1) and the strategy adopted by Chandran et al., who combined in the same HA structure strontium and adipose derived mesenchymal stem cells. In the first research, the regeneration capability of nanocrystalline hydroxyapatite with (HA/col-1) or without collagen-type I (HA) was evaluated in comparison to empty defect. Also, alt:V identified defined ROIs: ROI1 corresponding to the initial defect region and ROI2 corresponding to a region with a distance of $1 \mathrm{~mm}$ to the initially created defect where host bone-defect/biomaterial interface was present. Comparable new bone formation in ROI1 was measured for both HA and HA/col-1 group in comparison to the empty defect group, while in the ROI2, the highest BV/TV and the smallest Tb. Sp. were obtained for HA in comparison to the other groups. HA/col-1 yielded the highest connectivity density and the highest trabecular number. Surprisingly, the functionalization with collagen type-I (to enhance cells adhesiveness by transmembrane integrin receptors) did not induce a significant enhancement of performance in comparison with nanoHA, maybe suggesting a key role exerted by nanostructure in this experimental set-up [65,66]. On the contrary, Chandran S., obtained the highest $\mathrm{BV} / \mathrm{TV}$ values in defects treated with the synergistic functionalization of HA with the therapeutic and regulating effect Strontium and the osteogenic efficacy of adipose derived mesenchymal cells (ADMSCs) in comparison with HA, Sr-HA and ADMSCs-HA [66].

\subsubsection{Clinical Studies}

The clinical studies included in the review were five: $2 / 5$ used ceramics for hip arthroplasty, while $3 / 5$ studies used ceramic sticks or cement for spinal surgery. There was no mention on the micro or nanoscale of ceramics, as well as no testing of the functionalization of the ceramics (Table A3 in Appendix A).

Papers by Aro and Lee reported results of using ceramic coated prosthesis for hip primary replacements, both using stem prosthesis with an HA coated neck [67] or entirely HA coated [68]. 
In both studies, groups of patients implanted with non-HA-coated stems have not been reported; so far conclusions about the efficacy of using ceramic coatings to improve prosthesis osteointegration in OP patients cannot be drawn.

Aro et al. performed analyses during a 2-year single-centre prospective non controlled study on 39 female patients affected by osteoarthritis (OA) and requiring hip arthroplasty. Also, bone status was assessed by dual-energy X-ray absorptiometry (DEXA). RSA analysis (rotation, translation of the stem and osteointegration and clinical assessments (Harris hip and WOMAC scores) assessed that low BMD and ageing adversely affected initial stability of HA-coated implants and delayed osseointegration [67]. Lee et al. retrospectively evaluated 87 cementless long-stem prostheses extensively coated with HA in osteoporotic patients (mean $T$ score -3.0 , range, -2.5 to -6.3 ) affected by intertrochanteric fractures. Radiological and clinical analysis detected cortical porosis in the $37.5 \%$ of cases, acetabular erosion in $4.2 \%$, heterotopic ossification in $6.3 \%$ while no subsidence, no failure of leg length equalization and no osteolysis, suggesting that HA coated long stems relieve pain, restore function, provide long-term stability with few complications comparable or better than using cemented prosthesis [68].

The other three clinical studies considered ceramic based cements or sticks for augmentation in spinal surgical procedures, such as kyphoplasty [69] or interbody fusion [70,71]. The studies of Shin et al. and Jang et al. have a comparator control arms consisting of empty controls rather than a clinically accepted control material.

In a prospective comparative study, Shin and colleagues applied HA sticks for pedicle screw augmentation in 22 OP $(T$ value $\leq-2.5)$ and non-osteoporotic $(T$ value $>-2.5)$ patients affected by degenerative lumbar spine diseases and undergoing to interbody spinal fusion surgery. Results at 2 years highlighted that insertion with HA sticks significantly increased Torque values than without HA insertion in both OP and non-osteoporotic patients with significant higher values in the non-osteoporotic group than in the OP one. There were differences in bone sclerosis between HA and control groups, regardless of the presence of $\mathrm{OP}$, while no differences in loosening events and clinical assessments have been observed. The authors concluded that HA stick augmentation enhanced initial pedicle screw fixation strength in OP patients.

Jang et al. retrospectively evaluated 34 osteoporotic patients ( $T$-score of -2.5 or less) affected by spondylolisthesis and requiring transforaminal lumbar interbody fusion with polyethyetherketone (PEEK) cages: some patients received an additional screw augmentation with HA cement. Analyses conducted postoperatively up to the 2-year follow-up showed that in the group of patients augmented with HA cement there were no significant changes in radiologic parameters, differently from the non-augmented ones. Although not significantly, the visual analogue scale (VAS) and fusion rate were superior in HA cement treated patients. The authors concluded that screw augmentation with HA cements may be a useful tool in OP patients.

In a small cohort non-controlled retrospective study, Klein et al. [69] performed 24 kyphoplasties in $11 \mathrm{OP}$ patients using CaP cement, formed by micro-crystalline calcium-deficient HA. They followed patients up to 3 years, assessing that the intraosseous cement volumes slightly decreased every year; in only one case cement was found in the spinal canal without occurrence of any side effect. Vertebral stability increased significantly in the postop; pain and mobility scores significantly improved 2 years and 1 year after implantation, respectively. The authors concluded that $\mathrm{CaP}$ cement could be a safe and effective material with clinical and structural results comparable to poly methyl methacrylate (PMMA)-based materials also for the treatment of osteoporotic vertebral fractures.

\section{Discussion}

The burden of OP fractures is increasing, especially in population over 60 years old, imposing a significant economic impact on society. As recently reported by the International Osteoporosis Foundation, the estimated number of hip fractures worldwide will reach the 6.26 million in 2050 with a projected increase by $240 \%$ in women and $310 \%$ in men [72]. The cost associated with the fracture treatment in the US is around $\$ 17.9$ billion per annum while in the EU equates to $€ 24$ billion, even if 
considering the indirect costs, as long-term care and fracture prevention therapies, the amount rises to $€ 37$ billion per year [73].

Osteoporotic bone fracture represents a challenge intervention as the reduced mineral density, the bone micro-architectural deterioration and mechanical and structural modification of bone properties faced the surgeon and patient with a complex situation which compromises the achievement of a stable implant fixation and osseointegration [74]. Currently, in the clinical scenario, cements like PMMA or CaP represent the most commonly used biomaterials to treat osteoporotic fractures, especially at the spine level, in addition to metallic prostheses and osteosynthesis devices, nevertheless, new strategies are emerging to achieve better results in terms of osteointegration in compromised conditions.

In the present systematic review, the role of functionalization of ceramic materials or coatings with organic or inorganic molecules on osteointegration process in osteoporotic/osteopenic bone was evaluated from the preclinical and clinical point of view. The key role of the osteoconductive effects of ceramic materials on implant osteointegration in OP has already been reported, showing a better outcome in terms of BIC percentage and mechanical push-out test of CaP coated materials in comparison to non-coated implants [16].

The interface between bone and implant is a complex microenvironment, in which different "state" of the bone coexist: native bone, with an equilibrated homeostasis, peri-implant bone, which is driven to the onset of regeneration process and the newly formed bone. The deeper knowledge of bone structure and of the mechanisms of bone regeneration had helped to understand how to improve material design, at the micro and nanometric level, to obtain better and faster osteointegrative performance, also in terms of biomechanical competence [75].

Materials topography and geometries surely influence bone response and should balance the different forces (compressive, tensile and shear forces) which play a role in implant integration.

Increasing material roughness is a consolidated strategy to enhance osteointegration, as irregularity on the surface improve bone to implant contact and seems to guarantee a better biomechanical anchorage [76].

In the case of ceramic materials, it is well established that biological properties (osteoinductive and osteoconductive abilities) are also related to the synthesis process, in particular density, grain size, micro and macroporosity, pore dimension and interconnection, surface and bulk chemistry. For instance, some authors found that a decrease in ceramic particle size is related with a decrease in the inflammatory reaction $[77,78]$. Laquerriere et al. demonstrated the correlation between the secretion of inflammatory cytokines and ceramic particles sintered at high temperature [79]. The osteointegrative process is also critically dependent on surface charge and wettability, as well as nanotopography and microporosity.

Starting from this background and considering the increasing interest in the field of biomaterials functionalization, this review provides a picture of the currently studied and used molecules exploited to functionalize ceramic materials or coatings.

Most of the functionalization found in the present review involved changes in the chemical structure of ceramic materials by means the ionic substitution/enrichment with relevant ionic species $\left(\mathrm{Sr}^{2+}, \mathrm{Mg}^{2+}\right.$, $\mathrm{Zn}^{2+}, \mathrm{SiO}_{3}{ }^{2+}, \mathrm{SiO}_{4}{ }^{2-}$ ). Through a process of a co-precipitation, the composition, energy and/or surface charge of the material are changed with a substantial modification of the physicochemical properties and the bioactivity of the ceramic material. This approach leads to a larger, effective functionalized area and 3D distribution of trace elements throughout the bulk material. Even small amounts of these ionic species substitutes in the structure of ceramics exert a significant effect on thermal stability, solubility, osteoclastic and osteoblastic responses, degradation and bone regeneration [53,54,80-84].

Another interesting and unusual element adopted as inorganic components in the functionalization was lithium: after an initial observation of beneficial effect on bone status in patients undergoing lithium therapy for mental disorders, lithium proved to promote osteogenic differentiation, via activation of the Wnt signalling pathway, inhibiting glycogen synthase kinase-3beta (GSK-3 $\beta$ ) [85]. 
Always through a process of co-precipitation or chemisorption, $\mathrm{CaP}$ biomaterials can be functionalized with bisphosphonates (i.e. ALN, RA or ZOL), the major class of antiresorptive drugs used in clinics to inhibit bone loss thus preventing fracture occurrence. In fact, the local use of BPs is adopted to increase bone density preventing bone loss thank to its anti-resorptive capacity and seems to have also a positive effect in modulating the timing of ceramic dissolution, which influences not only bone growth but also the release of loaded drugs or molecules [51,52,62,86-89].

Chemical or physical changes at the titanium implant surfaces realized with alkali treatment, acid etching or anodic oxidation serves for acceleration and promoting the CaP coating adhesion. Physical immobilization (loading, dipping or adsorption) or chemical covalent immobilization represents the main functionalization strategies adopted to provide biological cues as drugs, growth factors, peptide or cells at the CaP coating surfaces. [4]

Alongside these types of "traditional" functionalization, focused on implementing the early adhesion of the host bone to the implant and therefore aimed at favouring the primary stability, more innovative approaches have been investigated. Examples are the functionalization with components of the ECM of bone like collagen type I or fibronectin involved in the modulation of cells behaviour through sequences recognized by cells integrin receptors or hyaluronic acid, glycosaminoglycan with a role in tissue support, lubrication and viscoelasticity modulation.

Bone tissue is also responsive to specific growth factors or hormones. Thus, the localized and controlled delivery of these bioactive molecules enhance the efficiency of bone regeneration as demonstrated by the functionalization with BB-1, a mutant BMP with enhanced osteogenic capacity comparable to that of BMP-2 or with VEGF or rhNELL-1 an osteoinductive factor with osteogenic and anti-osteoclastic properties.

Among the exploited growth factors, very interesting was the functionalization with BDNF. The choice of BDNF lays in the increasing evidence of its involvement in bone fracture healing, assessed in rodent models. Besides the role played during inflammatory response and enhancing angiogenic process, BDNF acts via TrkB-cRaf-ERK1/2-Elk1 signalling pathway enhancing the activity of osteoblasts and osteoblast-like cells, influencing ALP, BMP and OPN levels [90]. Others used anabolic factors comprise the application of statins that came from the evidence that patients undergoing therapy for hypercholesterolemia seemed to have a better bone status, probably thanks to the action on an enzyme in the mevalonate pathway downstream of HMG-CoA reductase, involved in bone loss. Despite indications in this sense are not so clear, it is instead assessed the ability of statins to increase VEGF and BMP-2 levels, being involved in bone regeneration processes [91]. Melatonin functionalization is also tested as the relationship between melatonin and bone health has been the object of discussion for many years. Many in vitro studies evidenced trophic effects on bone metabolism and cells, promoting osteoblast differentiation and increasing levels of bone formation markers. In addition, the inhibitor effect of Mel on inducible nitric oxide synthases (iNOS), which is involved in the onset of osteoporotic processes, make this hormone particularly suitable to be used in condition of compromised bone metabolism [92]. Finally, icariin is a well-established drug of traditional Chinese medicine, used for different disorders, including those affecting joints and for the treatment of osteoporosis. Icariin acts by increasing OPG/RANK ratio, TGF- $\beta 1$, insulin growth factor 1 (IGF-1) and bone related proteins as osteopontin, osteocalcin, bone sialoprotein, enhancing bone formation [93].

All these functionalization strategies arisen from the present systematic review follow the compelling need to limit bone resorption and at the same time to stimulate bone deposition around ceramics. In fact, the foreign body response to differently reabsorbable materials, such as ceramics, is a great concern particularly in a compromised microenvironment, as in OP. When a prosthetic material is implanted, the process of osseointegration occurs through the establishment of the foreign body equilibrium [94] that has to be maintained as long as possible. Within bone, macrophages exert a pivotal role on one hand in driving the transition between the M1 inflammatory phenotype in the early reparative phase and the M2 anti-inflammatory phenotype in the later stages [94] and secondly being precursors of osteoclasts. 
Ceramic coatings under loading conditions are subjected to wear and fragmentation, leading to the generation of particles. If the foreign body equilibrium is lost, repeated events of phagocytosis of ceramic particles maintain and strengthen the M1 inflammatory phenotype stimulating an inflammatory cascade, involving different cells (mainly monocytes/macrophages, polymorphonuclear cells and multinucleated giant cells) and growth factor and cytokine production (IL1, IL8, TNF-a, MMPs) that ultimately cause osteoclast activation, bone resorption and peri-implant osteolysis [95].

Inflammatory, cellular and biological responses to ceramics are particularly relevant in an OP microenvironment, in which the balance between osteoblasts and osteoclasts is already altered and the foreign body equilibrium is more difficult to maintain. Thus, the need of ceramics that are able to modulate and limit bone resorption is compelling.

Two papers take into consideration a functionalization strategy based on the use of autologous cells, OPG gene-modified BMSCs and ADSCs, respectively. Considering the ever-increasing use of cellular adjuvants in many fields of regenerative medicine, it would be expected more advanced studies on this innovative biotechnology. In both studies, the functionalization with mesenchymal stem cells play a key role in bone regeneration and repair processes thanks to their osteogenic differentiation and paracrine and trophic activities [37,49]. However, it must be taken into consideration that this type of functionalization would be related to an allogenic harvesting of BMSC or ADSC in clinical practice to obviate at the osteoporotic condition. Therefore, concerns exist related to harvesting procedure and morbidity for the patient, as well as concerns pertaining to the translation of this type of strategy to clinics relying on the need of an authorized cell factory to manipulate cells with inherent direct and indirect costs.

Surprisingly, the use of nanostructured ceramic materials is exploited in few papers: that is, Kettenberger et al. evaluated a $n$ HA combined with hyaluronic acid hydrogel with or without ZOL [24], while Alt. et al. studies $n \mathrm{HA}$ with or without collagen [65]. In both studies the authors did not observe statistically significant differences between functionalized groups and $n \mathrm{HA}$, thus suggesting a significant role played by the nanostructured size of ceramic in the osteoporotic condition capable of obtaining comparable results to the functionalized groups (Figure 2).

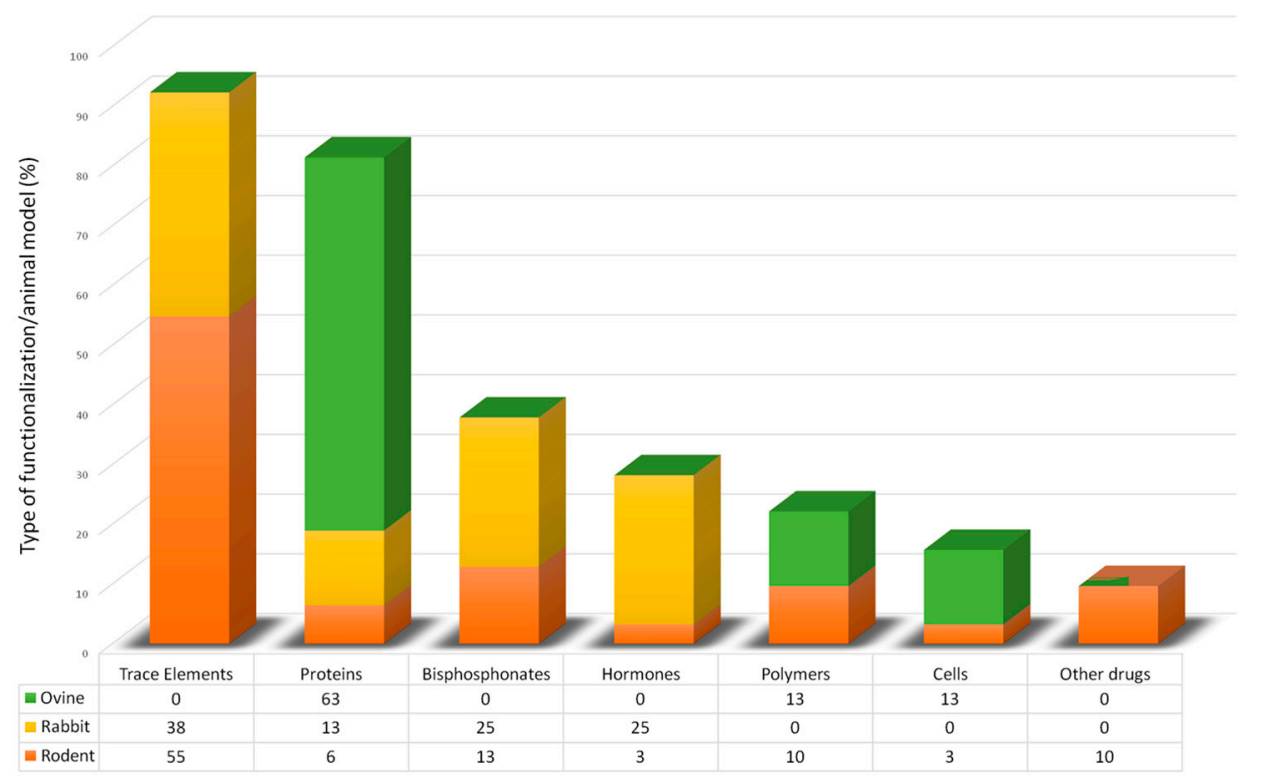

Figure 2. Analysis of the type of functionalization described in the preclinical papers.

A non-negligible result that emerges from the revision work is related to the significant discrepancies in the experimental settings adopted, even in the context of papers adopting the same animal model: namely, OP induction, implantation surgery, confirmation of osteoporosis development, anatomical site of implant, number of animals and type of materials. Preclinical studies were representative mainly of post-menopausal and glucocorticoid induced secondary osteoporosis 
and only one study evaluated male OVX. Thus, there is the lack of testing models that mimic OVX and osteopenia secondary to ageing or harmful lifestyles, such as sedentary habits or alcohol and tobacco consumption. According to the author, these aspects, in a rapidly ageing population, should be carefully evaluated. A wide range in the waiting time between the OVX and implantation surgeries has been found: from 3 to 12 weeks for rats and from 3 to 10 months for sheep. These relevant differences make the comparison between studies difficult. In addition, in some papers, evaluations for the confirmation of the onset of osteoporotic state development were not performed. Despite ovariectomy surgery now being a standardized and recognized procedure, the measurement of BMD is mandatory to properly evaluate obtained results (Figure 3).

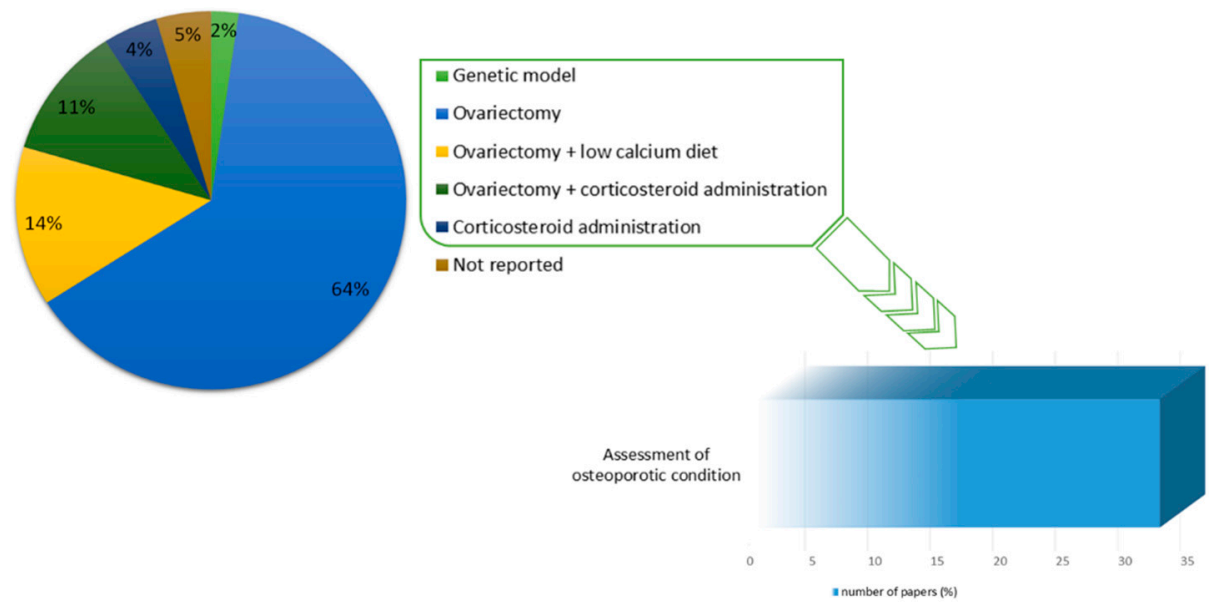

Figure 3. Pie chart of the methods used for inducing osteoporosis in the preclinical models. Histogram shows the percentage of preclinical studies reporting to have performed assessments of the establishment of the osteoporotic condition before implantation surgery $(33 \%)$.

Rodents still represent the most used type of animal model; a quick overview on the preferred site of implants shows, as expected, that the majority of tested materials formulations are placed in long bones (usually femurs) and vertebrae (mainly in ovine model), classical anatomical sites evaluated in cases of OP. Moreover, maxillofacial implants are less frequent, with 2 studies in which the mandible was the implant site, although recent literature highlights that oestrogen loss strongly influences bone resorption in the mandible [96] and clinical evidence have shown that the depth of mandibular incisure can be evaluated for early detection of OP [97]. Critical size defects are also performed in calvaria bone, despite even in this case where there are only few works about but this site is more and more used for studies related to OP [98,99] (Figure 4).

In almost all of the evaluated studies microtomography, histology and histomorphometry concur in the evaluation of osseointegration: bone volume/total volume (BV/TV), trabecular bone parameters, bone to implant contact and bone density represent the main evaluated parameters. Also, mechanical tests are represented, underlying an interest not only in bone regeneration but also in the evaluation of the quality of newly formed bone and implant stability.

To summarize, in all the considered approaches, the improvement of osseointegration parameters is probably due to the synergistic effect provided by the dissolution of the ceramic material and the anti-resorptive or anabolic effect of elements, drugs and growth factors. It remains to verify the extent, both spatially and temporally, of the effect induced by the functionalization strategies: only 3 papers take into consideration the extent of the observed effect, reporting a loss of significance of a few millimetres away from the implant $[62,63,65]$.

Alongside the innovative functionalization strategies and approaches proposed in the preclinical field, the clinical scenario did not present any of the aforementioned approaches. Most of the clinical studies were retrospective (3/5) in small groups of patients with a follow-up that ranged between 1 and 3 years. The investigated ceramic implants were commercially available products without 
functionalization and without any information about the micro- or nano- topography, probably due to the registered trademarks. All the studies agree that in osteoporotic patients, CaP materials or coating restore function, enhancing initial implant fixation strength and that low BMD, as well as ageing, affects the initial implant stability and delayed osseointegration, even for ceramic coated stems.

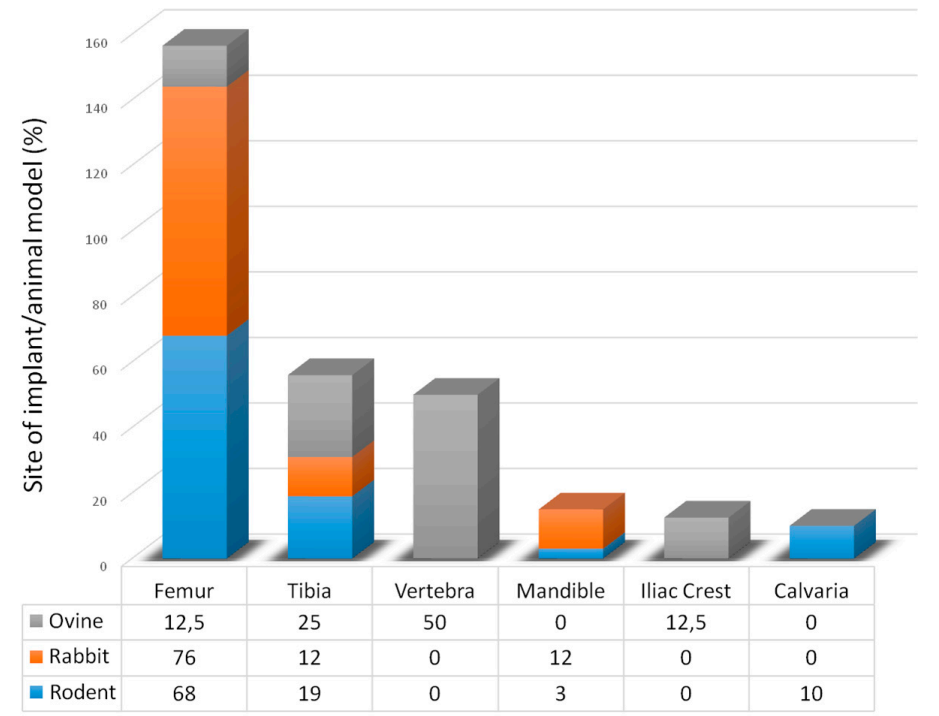

Figure 4. Analysis of the site of implant of functionalized materials described in the preclinical papers.

\section{Conclusions}

The illustrated results clearly show that functionalization strategies significantly improve osseointegration, representing a viable option in the treatment of osteoporotic fracture. Nevertheless, this improvement is probably affected by a limited range in terms of extension and further in-depth investigations are surely mandatory to clarify these aspects, beyond all the biological mechanisms driving tissue responses to functionalized implants. Although the clinical application of these advances is yet to be fully finalized, functionalization certainly promises to represent a winning strategy to improve the primary stability of implants and to ensure a quicker functional recovery of patient life quality.

Funding: This research was partly funded by National Funding Organizations (Ministero della Salute-IMH) under the frame of EuroNanoMed III Project "Next generation antibacterial nanostructured osseointegrated customized vertebral replacement-NANOVERTEBRA" Joint Transnational call for proposals (JTC 2018) and partly by Ricerca Corrente to the IRCCS-Istituto Ortopedico Rizzoli.

Conflicts of Interest: The authors declare no conflict of interest.

\section{Abbreviations}

mAChR muscarinic acetylcholine receptors

KO knock out

MBG morcellized bone graft

HR SEM high resolution scanning electron microscopy

EDS energy dispersive X-ray spectrometry

MAR mineral apposition rate

$\mathrm{H} / \mathrm{E}$ hematoxylin/eosin

CRP $\quad C$ reactive protein

ALP alkaline phosphatase

ICP-AES inductively coupled plasma atomic emission spectroscopy

FESEM field emission scanning electron microscopy

CatK cathepsin K

XPS X-ray photoelectron spectroscopy 


\section{Appendix A}

Table A1. Data extraction from small animal models (mouse and rat) research.

\begin{tabular}{|c|c|c|c|c|c|}
\hline Animal Model & $\begin{array}{c}\text { No. of Animals and Site of } \\
\text { Implant }\end{array}$ & $\begin{array}{c}\text { Materials Characteristics and } \\
\text { Functionalization }\end{array}$ & Experimental Set-up & Main Results & Ref. \\
\hline $\begin{array}{l}\text { Female homozygous } \\
\text { M3 mA ChR KO } \\
\text { breeder mice } \\
\text { (16-week-old) }\end{array}$ & $\begin{array}{l}87 \text { female } \\
\text { bicortical osteotomy of } \\
1.2 \mathrm{~mm} \text { in right distal femoral } \\
\text { metaphysis }\end{array}$ & $\begin{array}{l}\text { A composite of } \alpha \text {-TCP-based HA-forming } \\
\text { bone cement containing mesoporous } \\
\text { bioactive } \mathrm{CaP}^{-} \mathrm{SiO}_{2} \text { glass particles } \\
\text { (cement/MBG composite) MBG was } \\
\text { functionalized by loading with BDNF } \\
(84.1 \mathrm{ng} / \mathrm{g}) \text {. }\end{array}$ & $\begin{array}{l}\text { Group I: KO mice treated with cement/MBG composite with BDNF } \\
\text { Group II: KO mice treated with cement/MBG composite without BDNF } \\
\text { Group III: WT mice treated with cement/MBG composite with BDNF } \\
\text { Group IV: WT mice treated with cement/MBG composite without BDNF } \\
\text { Experimental times: } 35 \text { days } \\
\text {-Real-Time RT-PCR on homogenized tissue } \\
\text {-Ex vivo microCT } \\
\text {-Histology } \\
\text {-Histomorphometrical Analysis: } \\
\text {-ToF-SIMS, HR-SEM and EDS }\end{array}$ & $\begin{array}{l}\text { Results show effectiveness of } \\
\text { BDNF-functionalization but only in } \\
\text { WT group. } \\
\text { Real-Time RT-PCR: } \\
\uparrow \text { bone formation and ALP concentration } \\
\text { and } \downarrow \text { CRP levels in OVX mice with } \\
\text { cement/MBG composite without BDNF. } \\
\text { Histology/histomorphometry: } \\
\uparrow \text { newly formed bone } \\
\text { ToF-SIMS, HR-SEM and EDS: } \\
\text { bone formation inside pores of material }\end{array}$ & [21] \\
\hline $\begin{array}{l}\text { Skeletally-mature } \\
\text { male Wistar rats } \\
\text { (12-weeks old) } \\
\text { Orchidectomy surgery } \\
\text { OP assessment after } \\
6 \text { weeks: in vivo } \mu \mathrm{CT}\end{array}$ & $\begin{array}{l}60 \text { rats } \\
\text { Femoral condyles bilaterally } \\
\text { (diameter: } 1.5 \mathrm{~mm} \text {, depth: } \\
7 \mathrm{~mm} \text { ) }\end{array}$ & $\begin{array}{l}\text { Electrostatic Spray Deposition was used to } \\
\text { create a surface coating onto titanium } \\
\text { implant of: } \\
n \text { CaP crystals: } \\
\text { suspension of } \mathrm{Ca}\left(\mathrm{CH}_{3} \mathrm{COO}\right)_{2}(0.35 \mathrm{M}) \text { by } \\
\text { slow addition of an aqueous solution of } \\
\mathrm{H}_{3} \mathrm{PO}_{4}(0.21 \mathrm{M}) \\
n \mathrm{CaP} / \mathrm{BP} \text { coatings: alendronate sodium } \\
\text { trihydrate } \geq 97 \% \text { powder added to a } \\
\text { suspension containing } n \text { CaP crystals } \\
\text { (concentration } 3 \mathrm{mg} / \mathrm{mL} \text { and weight ratio } \\
\text { of } 1: 10) \text {. } \\
\text { BP coatings: alendronate sodium powder } \\
\text { was dissolved in milli- } \mathrm{Q} \text { and adjusted with } \\
\text { ethanol (final concentration } 0.3 \mathrm{mg} / \mathrm{mL})\end{array}$ & $\begin{array}{l}\text { Group I: OVX with non-coated implant } \\
\text { Group II: OVX with } n \mathrm{CaP} \text { implant } \\
\text { Group III: OVX with } n \mathrm{CaP} / \mathrm{BP} \text { implant } \\
\text { Group IV: OVX with BP implant } \\
\text { Group V: SHAM with non-coated implant } \\
\text { Group VI: SHAM with } n \mathrm{CaP} \text { implant } \\
\text { Group VII: SHAM with } n \mathrm{CaP} / \mathrm{BP} \text { implant } \\
\text { Group VIII: SHAM with BP implant } \\
\text { Experimental time: } 4 \text { weeks } \\
\text {-Ex-vivo microCT } \\
\text {-Histology in PMMA } \\
\text {-Histomorphometry } \\
\text {-Real-Time RT PCR }\end{array}$ & $\begin{array}{l}\text { MicroCT/ histomorphometry: } \\
\uparrow \% \text { BV (mCT) and BA (histomorphometry) } \\
\text { in OVX and sham groups with BP coating. } \\
\uparrow \text { both BIC and BV in } n \text { CaP/BP implant vs. } \\
n \text { CaP or BPs alone, in OVX and } \\
\text { healthy groups. }\end{array}$ & [22] \\
\hline $\begin{array}{l}\text { Female } \\
\text { Sprague-Dawley rats } \\
\text { (10 weeks old) } \\
\text { Ovariectomy } \\
\text { OP assessment } \\
\text { After } 8 \text { weeks: DEXA }\end{array}$ & $\begin{array}{l}60 \text { rats } \\
\text { distal right femoral growth } \\
\text { line in the lateral femoral } \\
\text { cortex and the metaphyseal } \\
\text { cancellous bone filled with } \\
0.25 \mathrm{~mL} \text { of each material }\end{array}$ & $\begin{array}{l}\text { Strontium enriched calcium phosphate } \\
\text { cement (SPC) in the solid phase in } \\
\text { comparison to calcium phosphate cement } \\
\text { (CPC) }\end{array}$ & $\begin{array}{l}\text { Group I: OVX with CPC material } \\
\text { Group II: OVX with SPC material } \\
\text { Experimental time: } 3 \text { and } 6 \text { months } \\
\text {-Histology in acrylic resin } \\
\text {-Histomorphometry } \\
\text {-DEXA }\end{array}$ & $\begin{array}{l}\text { Histomorphometry: } \\
\uparrow \text { Circumferential contact index for SrPC } \\
\text { vs. CPC at } 3 \text { months } \\
\uparrow \text { Ingrowth index for SrPC vs. CPC at } \\
6 \text { months } \\
\uparrow \text { Implant discontinuities for SrPC vs. CPC } \\
\text { at } 3 \text { and } 6 \text { months }\end{array}$ & [35] \\
\hline $\begin{array}{l}\text { Female } \\
\text { Sprague-Dawley rats } \\
\text { (12 months old) } \\
\text { Ovariectomy }\end{array}$ & $\begin{array}{l}64 \text { rats } \\
\text { Distal femur bilaterally } \\
\text { (7-11 granules/defect) }\end{array}$ & $\begin{array}{l}\text { Strontium enriched CaP particles }(\mathrm{SCP}) \\
\text { realized adopting a surfactant-free } \\
\text { mineralization method. Teflon plate with } \\
\text { holes in diameter of } 1.5 \mathrm{~mm} \text { and height of } \\
1.5 \mathrm{~mm} \text {, was used to produce } \mathrm{SCP} \text { and } \\
\text { HA granules. }\end{array}$ & $\begin{array}{l}\text { Group I: OVX with HA doped implants } \\
\text { Group II: OVX with SCP doped implants } \\
\text { Group III: SHAM with HA doped implants } \\
\text { Group IV: SHAM with SCP doped implants } \\
\text { Experimental time: } 6 \text { and } 28 \text { days } \\
\text {-Material characterization } \\
\text {-Gene expression } \\
\text {-Histology }\end{array}$ & $\begin{array}{l}\uparrow \text { TNF- } \alpha \text { in SHAM and OVX HA group at } \\
6 \text { days; } \\
\uparrow \text { IL- } 6 \text { in SHAM SrCP group at } 6 \text { and } 28 \mathrm{~d} \\
\text { Similar expression of RANKL } \\
\uparrow \text { CR and CatK in SHAM and OVX } \\
\text { HA group }\end{array}$ & [36] \\
\hline
\end{tabular}


Table A1. Cont.

\begin{tabular}{|c|c|c|c|c|c|}
\hline Animal Model & $\begin{array}{l}\text { No. of Animals and Site of } \\
\text { Implant }\end{array}$ & $\begin{array}{l}\text { Materials Characteristics and } \\
\text { Functionalization }\end{array}$ & Experimental Set-up & Main Results & Ref. \\
\hline $\begin{array}{l}\text { Female Wistar rats } \\
\text { ( } 3 \text { months old }) \\
\text { Ovariectomy } \\
\text { OP assessment after } \\
10 \text { months: ex vivo } \\
\text { microCT in } 10 \text { rats }\end{array}$ & $\begin{array}{l}9 \text { rats } \\
\text { drill hole defect of } \\
3 \mathrm{~mm} \times 1.5 \mathrm{~mm} \text { was made at } \\
\text { the proximal end of each } \\
\text { femur (two defect sites were } \\
\text { made available in } \\
\text { each animal) }\end{array}$ & $\begin{array}{l}\text { Strontium enriched }(10 \%) \mathrm{HA} \\
\text { micro-granules obtained by with wet } \\
\text { precipitation method. }\end{array}$ & $\begin{array}{l}\text { Group I: OVX with HA granules } \\
\text { Group II: OVX with SrHA granules } \\
\text { Group III: SHAM with HA granules } \\
\text { Group IV: SHAM with SrHA granules } \\
\text { Experimental time: } 8 \text { week } \\
\text {-Histology } \\
\text {-Histomorphometry }\end{array}$ & $\begin{array}{l}\text { Histomorphometry: } \\
\uparrow \text { regeneration efficacy in OVX SrHA group } \\
\uparrow \text { healing efficacy on par with material } \\
\text { resorption in SrHA group }\end{array}$ & [37] \\
\hline $\begin{array}{l}\text { Female } \\
\text { Sprague-Dawley rats } \\
\text { (4-month-old) } \\
\text { Ovariectomy and } \\
\text { calcium-, } \\
\text { phosphorous-, vitamin } \\
\text { D3-, soy- and } \\
\text { phytoestrogen-free } \\
\text { diet }\end{array}$ & $\begin{array}{l}65 \text { rats } \\
\text { After } 3 \text { months from OVX } \\
\text { surgery, wedge-shaped defect } \\
\text { with a lateral height of } 4 \mathrm{~mm} \\
\text { created at the metaphyseal } \\
\text { area of the femur }\end{array}$ & $\begin{array}{l}\text { Strontium enriched CPC (total Sr content } \\
\text { of 2.21\%) in the solid phase. } \\
\text { Composites of silica and fibrillar bovine } \\
\text { collagen as monolithic gel (B30, } 70 \mathrm{wt} \% \\
\text { silica, } 30 \mathrm{wt} \% \text { collagen) or as porous } \\
\text { scaffold (Sc-B30: B30 particles B30, size < } \\
250 \mu \mathrm{m} \text {, embedded in a collagen matrix } \\
\text { with xerogel/matrix weight ratio of } 1.0) \text {. } \\
\text { Composite porous scaffold of } 50 \mathrm{wt} \% \\
\text { silica, } \% \text { wt } \% \text { fibrillar bovine collagen and } \\
20 \mathrm{wt} \% \text { strontium carbonate (Sc-B30Sr20) } \\
\text { added to the collagen suspension. } \\
\end{array}$ & $\begin{array}{l}\text { Group I: control } \\
\text { Group II: CPC } \\
\text { Group III: SrCPC } \\
\text { Group IV: BC30- Monolithic xerogels (silica/collagen) } \\
\text { Group V: Scaffold xerogels particles B30 } \\
\text { Group VI: Scaffold xerogels particles (silica/fibrillar bovine } \\
\text { collagen/strontium carbonate) } \\
\text { Group VII: Iron foams } \\
\text { Group VIII: Iron foam with strontium } \\
\text { Group IX: Iron foam with ZOL } \\
\text { Experimental time: } 6 \text { weeks } \\
\text {-dPET-CT }\end{array}$ & $\begin{array}{l}\text { dPET-CT: } \\
\text { Sr release from SrCP cements increase } \\
\text { bone formation in comparison to CP } \\
\text { cement alone as well as the porous scaffold } \\
\text { silica/collagen xerogel in comparison to } \\
\text { monolithic silica/collagen xerogel }\end{array}$ & [39] \\
\hline $\begin{array}{l}\text { Female } \\
\text { Sprague-Dawley rats } \\
\text { (1 month old) } \\
\text { Ovariectomy }\end{array}$ & $\begin{array}{l}33 \text { rats } \\
\text { Critical-sized defects }(6 \mathrm{~mm} \times \\
6 \mathrm{~mm} \text { ) were created in the } \\
\text { calvarial bone. In the } \\
\text { scheduled groups, } \sim 325 \mu \mathrm{L} \\
\text { PRP was added to the } \\
\text { superior surface containing } \\
\text { the osteotomy }\end{array}$ & $\begin{array}{l}\text { Calcium aluminate (CA) disks prepared by } \\
\text { a room temperature cast of different sized } \\
\text { CA aggregates. Melatonin was chemically } \\
\text { attached to CA surface using a two-step } \\
\text { deposition process (Ca-Mel). }\end{array}$ & $\begin{array}{l}\text { Group I: CA } \\
\text { Group II: CA + PRP } \\
\text { Group III: CA-Mel } \\
\text { Group IV: CA-Mel + PRP } \\
\text { Experimental time: } 3 \text { and } 6 \text { months. } \\
\text {-X-ray } \\
\text {-Histology in resin }\end{array}$ & $\begin{array}{l}\text { Histology: } \\
\uparrow \text { percentage fluorescence in CA-Mel } \\
\text { groups vs. all other groups at } 6 \text { months } \\
\uparrow \text { osteoinductive and osteoconductive } \\
\text { activity of Ca-Mel scaffold vs. Ca scaffold. }\end{array}$ & [43] \\
\hline $\begin{array}{l}\text { Female } \\
\text { Sprague-Dawley rats: } \\
\text { Ovariectomy }\end{array}$ & $\begin{array}{l}36 \text { rats. After } 12 \text { weeks from } \\
\text { OVX surgery, two different } \\
\text { implants }(n=72) \text { were } \\
\text { inserted into the distal tibia }\end{array}$ & $\begin{array}{l}\text { Porous Ti implant }(2.2 \mathrm{~mm} \times 4 \mathrm{~mm}) \text { coated } \\
\text { with HA and HA-Simvastatin }(\mathrm{HA}-\mathrm{Sim}) \\
\text { applying an electrochemical } \\
\text { deposition process. }\end{array}$ & $\begin{array}{l}\text { Group I: HA coating } \\
\text { Group II: HA + Sim coating } \\
\text { Group III: control } \\
\text { Experimental time: } 2,4 \text { and } 12 \text { weeks } \\
\text {-Histology and Histomorphometry } \\
\end{array}$ & $\begin{array}{l}\text { Histomorphometry: } \\
\uparrow \text { BIC percentage in HA/Simvastatin group } \\
\text { vs. other groups at } 12 \text { weeks }\end{array}$ & [45] \\
\hline $\begin{array}{l}\text { Wistar Crl: WI (Han) } \\
\text { rats female, retired } \\
\text { breeders (8-10 months } \\
\text { old): Ovariectomy, } \\
\text { OP assessment after } \\
7 \text { months: pQCT }\end{array}$ & $\begin{array}{l}18 \text { rats. } 8 \text { weeks after OVX } \\
\text { surgery subcutaneously } \\
\text { injection of vehicle/ALN; } \\
13 \text { weeks atter OVX surgery } \\
\text { critical size defect }(5 \mathrm{~mm})\end{array}$ & $\begin{array}{l}\text { BMP2 or L51P were loaded onto } \beta \text {-TCP } \\
\text { cylinders by physical immobilization } \\
\text { (adsorption). }\end{array}$ & $\begin{array}{l}\text { Group I: unloaded } \\
\text { Group II: } 1 \mu \mathrm{g} \text { BMP2 } \\
\text { Group III: } 10 \mu \mathrm{g} \text { BMP2 } \\
\text { Group IV: } 10 \mu \mathrm{g} \text { L51P } \\
\text { Group V: } 1 \mu \mathrm{g} \text { BMP2/10 } \mu \mathrm{g} \text { L51P } \\
\text { Experimental time: } 16 \text { weeks } \\
\text {-x-ray } \\
\text {-ex vivo microCT } \\
\text {-Histology } \\
\text {-Histomorphometry } \\
\end{array}$ & $\begin{array}{l}\text { Histomorphometry: } \\
\uparrow \text { bone volume and } \downarrow \beta T C P \text { in group } V \\
\downarrow \beta T C P \text { turnover after ALN administration }\end{array}$ & [50] \\
\hline
\end{tabular}


Table A1. Cont.

\begin{tabular}{|c|c|c|c|c|c|}
\hline Animal Model & $\begin{array}{c}\text { No. of Animals and Site of } \\
\text { Implant }\end{array}$ & $\begin{array}{l}\text { Materials Characteristics and } \\
\text { Functionalization }\end{array}$ & Experimental Set-up & Main Results & Ref. \\
\hline $\begin{array}{l}\text { Mature female Wistar } \\
\text { rats ( } 3 \text { months old) } \\
\text { Ovariectomy + low } \\
\text { calcium diet } \\
\text { OP assessment after } \\
6 \text { weeks with in vivo } \\
\text { microCT in } 6 \text { animals }\end{array}$ & $\begin{array}{l}32 \text { rats. Bone defect created } \\
\text { bilaterally longitudinal to the } \\
\text { axis of the femur }\end{array}$ & $\begin{array}{l}\text { CPC/PLGA composite cylinders made of } \\
70 \mathrm{wt} \% \text { a-TCP powder and } 30 \mathrm{wt} \% \text { PLGA } \\
\text { powder, containing both a lactic and } \\
\text { glycolic weight percentage of } 50 \% \text { and } \\
0.5 \% \text { carboxymethylcellulose (CMC). }\end{array}$ & $\begin{array}{l}\text { Group I: OVX with Bio-Oss } \\
\text { Group II: OVX } \text { with CPC/PLGules } \\
\text { Group III: SHAM with Bio-Oss cylinders } \\
\text { Group IV: SHAM with CPC/PLGA cylinders } \\
\text { Experimental time: } 4 \text { and } 1 \text { weeks } \\
\text {-Fluorescence analysis } \\
\text {-Ex vivo microCT } \\
\text {-Histology } \\
\text {-Histomorphometry }\end{array}$ & $\begin{array}{l}\text { Histomorphometry: } \\
\uparrow \text { Bio- Oss degradation in comparison to } \\
\text { CPC/PLGA both in SHAM and OVX } \\
\uparrow \text { bone formation from the centre of the } \\
\text { defect with Bio- Oss in comparison to } \\
\text { CPC/PLGA both in SHAM and OVX }\end{array}$ & [40] \\
\hline $\begin{array}{l}\text { Female Wistar rats } \\
\text { (12 weeks old) } \\
\text { Ovariectomy }\end{array}$ & $\begin{array}{l}30 \text { rats } \\
\text { After } 4 \text { weeks from OVX } \\
\text { surgery, implantation in } \\
\text { proximal tibial growth plate }\end{array}$ & $\begin{array}{l}\text { Composite of biodegradable PLGA with } \\
\text { b-TCP screws }(1.6 \mathrm{~mm} \times 4 \mathrm{~mm})\end{array}$ & $\begin{array}{l}\text { Group I: SHAM group } \\
\text { Group II: OVX group } \\
\text { Group III: PLGA only group } \\
\text { Group IV: PLGA/ } \beta \text { TCP group } \\
\text { Experimental time: } 25 \text { weeks } \\
\text {-Ex vivo microCT } \\
\text {-Histology in paraffin } \\
\end{array}$ & $\begin{array}{l}\text { MicroCT: } \\
\uparrow \text { BMD, BV/TV and Tb.N } \\
\downarrow \text { Tb.Th and Tb.Sp in sham group. } \\
\uparrow \text { BMD in OVX/CSR group } \\
\uparrow \text { BV/TV and Tb.N values } \\
\downarrow \text { Tb.Sp than OVX and OVX/BSR }\end{array}$ & [42] \\
\hline $\begin{array}{l}\text { Virgin female Wistar } \\
\text { rats (17 weeks old) } \\
\text { Ovariectomy } \\
\text { OP assessment } 1 \text { day } \\
\text { before treatment: } \\
\text { in vivo microCT }\end{array}$ & $\begin{array}{l}8 \text { rats. After } 5 \text { weeks from } \\
\text { OVX surgery, implantation of } \\
\text { miniature screw in femoral } \\
\text { condyles bilaterally (same } \\
\text { implants for each animal). }\end{array}$ & $\begin{array}{l}\text { NanoHA particles added to an aqueous } \\
\text { solution of zoledronate (nHA:zoledronate } \\
\text { ratio of 100:1). } \\
\text { Hydrogel composed by hyaluronan } \\
\text { derivative and PVA crosslinker was used } \\
\text { to deliver nHA-zoledronate, } n \text { HA or } \\
\text { zolendronate. }\end{array}$ & $\begin{array}{l}\text { Group I: } n \mathrm{HA}-\mathrm{Gel} \\
\text { Group II: } n \mathrm{HA}-\mathrm{Zol}-\mathrm{Gel} \\
\text { Group III: Zol-Gel } \\
\text { Group IV: Gel } \\
\text { Experimental time: } 58 \text { weeks } \\
\text {-In vivo microCT } \\
\text {-Histology }\end{array}$ & $\begin{array}{l}\text { Histology: } \\
\uparrow \mathrm{MV} / \mathrm{TV} \text { in } n \text { HA-Gel vs. Gel alone } \\
\uparrow \mathrm{MV} / \mathrm{TV} \text { in } n \text { HA-Zol-Gel vs. Gel alone } \\
\text { ZOL-loaded } n \text { HA further inhibited a } \\
\text { degradation of the mineralized hydrogel as } \\
\text { well as a resorption of the peri-implant } \\
\text { bone as effectively as unbound ZOL. }\end{array}$ & [24] \\
\hline $\begin{array}{l}\text { Female } \\
\text { Sprague-Dawley } \\
\text { (three-month-old) } \\
\text { Ovariectomy } \\
\text { After } 12 \text { weeks OP } \\
\text { assessmentwith } \\
\text { histology in } 4 \text { rats }\end{array}$ & $\begin{array}{l}32 \text { rats } \\
\text { Bilateral implantation in } \\
\text { femoral medullary cavity }\end{array}$ & $\begin{array}{l}\text { Ti rods }(1.1 \mathrm{~mm} \times 12 \mathrm{~mm}) \text { and disks }(9 \mathrm{~mm} \\
\times 1 \mathrm{~mm}) \text { surfaced functionalized with } \\
\text { Zolendronate HA coating }(\mathrm{ZnHA}) \text { realized } \\
\text { with sol-gel dip technique. }\end{array}$ & $\begin{array}{l}\text { Group I: Zn coated Ti implant } \\
\text { Group II: ZnHA coated Ti implant } \\
\text { Experimental time: } 6 \text { and } 12 \text { weeks } \\
\text {-Material characterization } \\
\text {-Histology in PMMA } \\
\text {-Histomorphometry } \\
\text {-MicroCT } \\
\text {-Mechanical tests }\end{array}$ & $\begin{array}{l}\text { Histology/histomorphometry: } \\
\uparrow \mathrm{MAR}, \mathrm{BA} \text { and BIC values in ZnHA } \\
\text { coating group vs. HA coated group } \\
\uparrow \text { bone mass formation around the implant } \\
\uparrow \text { strength of osseointegration values in } \\
\text { ZnHA coating group vs. HA coated group } \\
\text { MicroCT analysis: } \\
\uparrow \mathrm{BV} / \mathrm{TV} \text { and OI\% in ZnHA coating group } \\
\text { vs. HA coated group } \\
\text { Mechanical tests: } \\
\uparrow \text { maximum force and interfacial shear } \\
\text { strenght in ZnHA coating group vs. HA } \\
\text { coated group }\end{array}$ & [25] \\
\hline
\end{tabular}


Table A1. Cont.

\begin{tabular}{|c|c|c|c|c|c|}
\hline Animal Model & $\begin{array}{c}\text { No. of Animals and Site of } \\
\text { Implant }\end{array}$ & $\begin{array}{l}\text { Materials Characteristics and } \\
\text { Functionalization }\end{array}$ & Experimental Set-up & Main Results & Ref. \\
\hline $\begin{array}{l}\text { Female Sprague } \\
\text { Dawley rat (3 months } \\
\text { old) } \\
\text { Ovariectomy } \\
\text { (12 weeks) }\end{array}$ & $\begin{array}{l}18 \text { rats } \\
\text { Bilateral implantation in } \\
\text { femoral medullary cavity }\end{array}$ & $\begin{array}{l}\text { Ti implants }(1.2 \mathrm{~mm}) \text { surfaced } \\
\text { functionalized with Magnesium HA } \\
\text { (MgHA) realized with sol-gel dip-coating } \\
\text { method }\left(10 \mathrm{~mol} \% \mathrm{Ca}^{2+} \text { replaced by } \mathrm{Mg}^{2+}\right) \text {. }\end{array}$ & $\begin{array}{l}\text { Group I: MgHA coated implant } \\
\text { Group II: HA coated implant } \\
\text { Experimental time: } 12 \text { weeks } \\
\text {-Material characterization } \\
\text {-Histology } \\
\text {-Histomorphometry } \\
\text {-Ex vivo microCT } \\
\text {-Mechanical tests } \\
\end{array}$ & $\begin{array}{l}\text { Histology: } \\
\uparrow \text { osteointegration and bone formation in } \\
\text { MgHA group } \\
\text { Ex vivo microCT: } \\
\uparrow \mathrm{BV} / \mathrm{TV}, \text { Tb.N, Tb.Th, Conn.D. and \%OI } \\
\text { Mechanical tests: } \\
\uparrow \text { maximum force and interfacial shear } \\
\text { strenght in MgHA group } \\
\end{array}$ & [26] \\
\hline $\begin{array}{l}\text { Female Sprague } \\
\text { Dawley (3-month-old) } \\
\text { Ovariectomy }\end{array}$ & $\begin{array}{l}20 \text { rats } \\
\text { After } 12 \text { weeks from OVX } \\
\text { surgery, bilateral implantation } \\
\text { in femoral medullary cavity }\end{array}$ & $\begin{array}{l}\text { HA and } 10 \% \text { Strontium enriched HA (HA } \\
\text { with } 10 \text { mol } \% \text { calcium substituted by } \\
\text { strontium) were obtained with chemical } \\
\text { co-precipitation method. }\end{array}$ & $\begin{array}{l}\text { Group I: HA coated implant } \\
\text { Group II: } 10 \% \text { SrHA coated implant } \\
\text { Experimental time: } 8 \text { weeks } \\
\text {-Material characterization } \\
\text {-Ex vivo microCT } \\
\text {-Histology in paraffin } \\
\text {-Histomorphometry }\end{array}$ & $\begin{array}{l}\text { Ex vivo microCT: } \\
\uparrow \text { Tb.N and Tb.Th in } 10 \% \text { Sr HA coating } \\
\text { group vs. HA coating alone } \\
\downarrow \text { Tb.Sp in } 10 \% \text { Sr HA coating group vs. } \\
\text { HA coating alone } \\
\text { Histomorphometry: } \\
\uparrow \mathrm{BV} \text {, BIC in } 10 \% \text { Sr HA coating group vs. } \\
\text { HA coating alone } \\
\end{array}$ & {$[27]$} \\
\hline $\begin{array}{l}\text { Female Sprague } \\
\text { Dawley rats } \\
\text { (3-month-old) } \\
\text { Ovariectomy } \\
\text { Zol administration } \\
\text { (1.5 lg/kg weekly) for } \\
12 \text { weeks }\end{array}$ & $\begin{array}{l}26 \text { rats } \\
\text { After } 12 \text { weeks from OVx } \\
\text { surgery, bilateral implantation } \\
\text { in femoral medullary cavity }\end{array}$ & $\begin{array}{l}\text { HA and } 10 \% \text { Strontium HA enriched (HA } \\
\text { with } 10 \text { mol\% calcium substituted by } \\
\text { strontium) were obtained with chemical } \\
\text { co-precipitation method. } \\
\text { Previous treatment with BPs }\end{array}$ & $\begin{array}{l}\text { Group I: HA coated implant } \\
\text { Group II: } 10 \% \text { SrHA coated implant } \\
\text { Experimental time: } 8 \text { weeks } \\
\text {-Material characterization } \\
\text {-Ex vivo microCT } \\
\text {-Histology } \\
\text {-Histomorphometry }\end{array}$ & $\begin{array}{l}\text { Ex vivo microCT: } \\
\uparrow \text { Tb.N and Tb.Th in } 10 \% \text { Sr HA coating } \\
\text { group vs. HA coating alone } \\
\downarrow \text { Tb.Sp in } 10 \% \text { Sr HA coating group vs. } \\
\text { HA coating alone } \\
\text { Histomorphometry } \\
\uparrow \mathrm{BV}, \mathrm{BA} \text { in } 10 \% \mathrm{Sr} \text { HA coating group vs. } \\
\text { HA coating alone } \\
\end{array}$ & {$[28]$} \\
\hline $\begin{array}{l}\text { Female } \\
\text { Sprague-Dawley } \\
\text { (6-month-old) } \\
\text { Ovariectomy } \\
\text { After } 12 \text { weeks OP } \\
\text { assessment with } \\
\text { microCT } \\
\end{array}$ & $\begin{array}{l}\text { Animals number not reported. } \\
6 \text { months after OVX surgery, } \\
\text { bilateral implantation at the } \\
\text { medial aspect of the tibial } \\
\text { shaft. }\end{array}$ & $\begin{array}{l}\text { Lithium enriched calcium phosphate } \\
\text { cement in the liquid phase }(\mathrm{Li} / \mathrm{CPC}) \text { and } \\
\text { realized as cylindrical implant }(2.5 \times 4) \text {. }\end{array}$ & $\begin{array}{l}\text { Group I: OVX with Li/CPC-100 } \\
\text { Group II: OVX with CPC } \\
\text { Experimental time: } 4 \text { and } 8 \text { weeks } \\
\text {-Material characterization } \\
\text {-Ex vivo microCT } \\
\text {-Histology }\end{array}$ & $\begin{array}{l}\text { Ex vivo microCT: } \\
\uparrow \mathrm{BV} / \mathrm{TV} \text { in } \mathrm{Li} / \mathrm{CPC}-100 \text { vs. CPC alone } \\
\text { Histology: } \\
\text { greater osteoconductivity and } \\
\text { osseointegration in Li/CPC group vs. CPC } \\
\text { alone }\end{array}$ & [44] \\
\hline $\begin{array}{l}\text { Female } \\
\text { Sprague-Dawley rats } \\
\text { Bilateral ovariectomy } \\
\text { (3 months) }\end{array}$ & $\begin{array}{l}36 \text { rats } \\
\text { Full-thickness } 5 \mathrm{~mm} \text { diameter } \\
\text { round bone defect made on } \\
\text { each side of the mandible }\end{array}$ & $\begin{array}{l}\text { Genetically modify BMSCs for OPG } \\
\text { overexpression seeded at } 2 \times 10^{5} \mathrm{~cm}^{-2} \\
\text { concentration onto HA scaffold } \\
(5 \mathrm{~mm} \times 1 \mathrm{~mm})\end{array}$ & $\begin{array}{l}\text { Group I: HA } \\
\text { Group II: BMSC/HA } \\
\text { Group III: OPG-BMSC/HA } \\
\text { Experimental times: } 4,6 \text { and } 8 \text { weeks } \\
\text {-Ex vivo microCT } \\
\text {-Histology in PMMA } \\
\text {-Immunohistochemistry }\end{array}$ & $\begin{array}{l}\text { Ex vivo microCT: } \\
\uparrow \text { MV/TV in OPG-BMSC/HA group at the } \\
\text { longest experimental times } \\
\text { Histology: } \\
\uparrow \text { mineralized new bone in } \\
\text { OPG-BMSC/HA group } \\
\downarrow \text { number of osteoclasts in } \\
\text { OPG-BMSC/HA group }\end{array}$ & [49] \\
\hline
\end{tabular}


Table A1. Cont.

\begin{tabular}{|c|c|c|c|c|c|}
\hline Animal Model & $\begin{array}{c}\text { No. of Animals and Site of } \\
\text { Implant }\end{array}$ & $\begin{array}{l}\text { Materials Characteristics and } \\
\text { Functionalization }\end{array}$ & Experimental Set-up & Main Results & Ref. \\
\hline $\begin{array}{l}\text { Female } \\
\text { Sprague-Dawley rats } \\
\text { (10 and } 11 \text { months old) } \\
\text { Ovariectomy } \\
\text { After } 3 \text { months OP } \\
\text { assessment with } \\
\text { microCT: BMD }\end{array}$ & $\begin{array}{l}42 \text { rats } \\
\text { Bilateral implantation in the } \\
\text { median aspect of the tibial } \\
\text { shaft, below the tibial plateau. }\end{array}$ & $\begin{array}{l}\beta-\mathrm{TCP} \text {, calcium silicate }(\mathrm{CS}) \text { and } 10 \% \\
\text { Strontium enriched CS (Sr-CS) } \\
(3 \mathrm{~mm} \times 3 \mathrm{~mm}) \text { obtained by a chemical } \\
\text { precipitation method. }\end{array}$ & $\begin{array}{l}\text { Group I: Blank } \\
\text { Group II: } \beta \text {-TCP } \\
\text { Group III: CS } \\
\text { Group IV: Sr-CS } \\
\text { Experimental times: } 3 \text { days, } 1,4 \text { and } 9 \text { weeks } \\
\text {-Material characterization EDX and SEM } \\
\text {-Detection of in vivo } \mu \text { e-pH } \\
\text {-MicroCT } \\
\text {-Histology }\end{array}$ & $\begin{array}{l}\text { MicroCT: } \\
\uparrow V_{\mathrm{NB}} / T_{\mathrm{V}} \text { in } \mathrm{CS} \text { and Sr-CS groups } \\
\text { Histology: } \\
\downarrow \text { TRAP staining positivity in CS and } \\
\text { Sr-CS groups } \\
\text { Alkaline materials induce an increase in } \\
\mu \mathrm{e}-\mathrm{pH}, \text { which is associated with higher } \\
\text { bone formation and delay in osteoclasts } \\
\text { activity. Residual materials is detectable up } \\
\text { to the latest experimental time. }\end{array}$ & [48] \\
\hline $\begin{array}{l}\text { Female } \\
\text { Sprague-Dawley rats } \\
\text { (8 weeks old) } \\
\text { Ovariectomy } \\
\text { (3 months) }\end{array}$ & $\begin{array}{l}20 \text { rats } \\
3 \text { months after OVX surgery, } \\
\text { bilateral implantation in the } \\
\text { proximal metaphyseal region } \\
\text { of the tibiae. }\end{array}$ & $\begin{array}{l}\text { Titanium screw coated with a biomimetic } \\
\text { CaP coating onto which Zolendronate was } \\
\text { immobilized by dipping at different } \\
\text { concentration }(0,8,80 \text { and } 800 \mu \mathrm{g} / \mathrm{mL}) \text {. }\end{array}$ & $\begin{array}{l}\text { Group I: control } \\
\text { Group II: } 8 \mu \mathrm{g} / \mathrm{mL} \\
\text { Group III: } 80 \mu \mathrm{g} / \mathrm{mL} \\
\text { Group IV: } 800 \mu \mathrm{g} / \mathrm{mL} \\
\text { Experimental times: } 8 \text { weeks } \\
\text {-Material characterization } \\
\text {-Histology } \\
\text {-Histomorphometry } \\
\text {-Ex vivo microCT }\end{array}$ & $\begin{array}{l}\text { Histomorphometry: } \\
\uparrow \mathrm{BV} \% \text { in group IV, no differences in BIC\% } \\
\text { between groups }\end{array}$ & [23] \\
\hline $\begin{array}{l}\text { Female Sprague } \\
\text { Dawley (12 weeks old) } \\
\text { Ovariectomy }\end{array}$ & $\begin{array}{l}\text { Animals number not reported } \\
4 \text { weeks after OVX surgery, } \\
\text { implantation in the lateral } \\
\text { femoral condyle }\end{array}$ & $\begin{array}{l}\text { Alendronate enriched } n \mathrm{HA}(\mathrm{HA}-\mathrm{AL}) \text {, } \\
\text { Fe3O4 enriched } n \mathrm{HA}(\mathrm{HAFe}) \text { and } \\
\text { Alendronate/ Fe3O4 enriched nHA crystals } \\
\text { synthesized by a wet chemical technique. } \\
\text { Spiral-cylindrical scaffolds } \\
(2.5 \mathrm{~mm} \times 3 \mathrm{~mm}) \text { were obtained by } \\
\text { a solvent-casting/particle-leaching using } \\
\text { polycaprolactone as polymer matrix. }\end{array}$ & $\begin{array}{l}\text { Group I: Blank } \\
\text { Group II: PCL } \\
\text { Group III: HA } \\
\text { Group IV: HA-AL2 } \\
\text { Group V: HA-Fe10 } \\
\text { Group VI: HA-AL2-Fe10 } \\
\text { Experimental times: } 4 \text { weeks } \\
\text {-MicroCT } \\
\text {-Histology } \\
\text {-Immunohistochemistry }\end{array}$ & $\begin{array}{l}\text { MicroCT: } \\
\uparrow \text { BMD, BV/TV, Conn.D, Tb.Th, Tb.N in } \\
\text { HA-AL2, HA-Fe10 and HA-AL2-Fe10 } \\
\text { groups vs. HA group } \\
\downarrow \text { Tb.Sp in HA-AL2, HA-Fe10 and } \\
\text { HA-AL2-Fe10 groups vs. HA group. } \\
\text { Histology: } \\
\text { Func-HA induces bone regeneration and } \\
\text { integration, increasing Coll and reducing } \\
\text { osteoclasts activity. }\end{array}$ & [41] \\
\hline $\begin{array}{l}\text { Female } \\
\text { Sprague-Dawley rats } \\
\text { ( } 3 \text { months old) } \\
\text { Ovariectomy } \\
\text { OP assessment after } \\
12 \text { weeks: ex-vivo } \\
\text { microCT in } 5 \text { ovx and } \\
5 \text { sham }\end{array}$ & $\begin{array}{l}50 \text { rats. Implantation in the } \\
\text { femoral medullary canal after } \\
\text { marrow ablation. all OVX rats } \\
\text { from the first two groups } \\
\text { received HA-coated implants } \\
\text { and those from latter two } \\
\text { groups got Sr-HA ones. }\end{array}$ & $\begin{array}{l}\text { Titanium screws }(1 \mathrm{~mm} \times 2 \mathrm{~mm}) \text { coated } \\
\text { with } 10 \% \text { Strontium enriched HA titanium } \\
\text { implant via electrochemical deposition }+ \\
\text { intermittent administration of human PTH } \\
(1-34)(60 \mathrm{mg} / \mathrm{kg}, 3 \text { times a week })\end{array}$ & $\begin{array}{l}\text { Group I: Sr } \\
\text { Group II: PTH } \\
\text { Group III: PTH/Sr } \\
\text { Experimental times: } 12 \text { weeks } \\
\text {-Ex vivo microCT } \\
\text {-Mechanical test } \\
\text {-Histology } \\
\text {-Histomoprhometry }\end{array}$ & $\begin{array}{l}\text { microCT: } \\
\uparrow \text { BV/TV, Tb.Th, Tb.N in PTH + Sr group } \\
\downarrow \text { in PTH + Sr group } \\
\text { Histomorphometry: } \\
\uparrow \text { BAR and BIC \% in PTH + Sr group } \\
\text { Mechanical test: } \\
\uparrow \text { push out force in PTH + Sr group }\end{array}$ & [30] \\
\hline $\begin{array}{l}\text { Female Sprague } \\
\text { Dawley rats ( } 3 \text { months } \\
\text { old) } \\
\text { Ovariectomy } \\
\text { OP assessment after } \\
12 \text { weeks: ex-vivo } \\
\text { microCT in } 5 \text { ovx and } \\
5 \text { sham }\end{array}$ & $\begin{array}{l}50 \text { rats } \\
\text { Implantation in the femoral } \\
\text { medullary canal after marrow } \\
\text { ablation. }\end{array}$ & $\begin{array}{l}\text { Titanium implants }(1.2 \mathrm{~mm} \times 15 \mathrm{~mm}) \\
\text { coated with Strontium enriched HA } \\
\text { (Sr-HA) coating at different contents via } \\
\text { electrochemical deposition. }\end{array}$ & $\begin{array}{l}\text { Group I: HA } \\
\text { Group II: } 5 \% \text { Sr-HA } \\
\text { Group III: } 10 \% \text { Sr-HA } \\
\text { Group IV: } 20 \% \text { Sr-HA } \\
\text { Experimental times: } 12 \text { weeks } \\
\text {-Material characterization } \\
\text {-Ex-vivo microCT } \\
\text {-Mechanical test } \\
\text {-Histology } \\
\text {-Histomorphometry }\end{array}$ & $\begin{array}{l}\text { MicroCT: } \\
\uparrow \text { BV/TV, Tb.Th, Tb.N, Conn.D in } 10 \text { and } \\
20 \% \text { SrHA groups } \\
\downarrow \text { Tb.Sp. in } 10 \% \text { and } 20 \% \text { SrHA groups } \\
\text { Histomorphometry: } \\
\uparrow \text { BAR and BIC } \% \text { in } 10 \% \text { and } 20 \% \\
\text { SrHA groups } \\
\text { Mechanical test: } \\
\uparrow \text { push out force in } 10 \% \text { and } 20 \% \\
\text { SrHA groups }\end{array}$ & [29] \\
\hline
\end{tabular}


Table A1. Cont.

\begin{tabular}{|c|c|c|c|c|c|}
\hline Animal Model & $\begin{array}{c}\text { No. of Animals and Site of } \\
\text { Implant }\end{array}$ & $\begin{array}{l}\text { Materials Characteristics and } \\
\text { Functionalization }\end{array}$ & Experimental Set-up & Main Results & Ref. \\
\hline $\begin{array}{l}\text { Female Sprague } \\
\text { Dawley rats (3 months } \\
\text { old) } \\
\text { Ovariectomy } \\
\text { OP assessment after } \\
12 \text { weeks: ex-vivo } \\
\text { microCT in } 5 \text { ovx and } \\
5 \text { sham }\end{array}$ & $\begin{array}{l}50 \text { rats } \\
\text { Implantation in the femoral } \\
\text { medullary canal after } \\
\text { marrow ablation. }\end{array}$ & $\begin{array}{l}\text { Titanium implants }(1 \mathrm{~mm} \times 2 \mathrm{~mm} \text { ) coated } \\
\text { with Strontium enriched HA (Sr-HA) or } \\
\text { zinc enriched HA (Zn-HA) or Magnesium } \\
\text { enriched HA (Mg-HA) coating via } \\
\text { electrochemical deposition. }\end{array}$ & $\begin{array}{l}\text { Group I: HA } \\
\text { Group II: Zn-HA } \\
\text { Group III: Mg-HA } \\
\text { Group IV: Sr-HA } \\
\text { Experimental times: } 12 \text { weeks } \\
\text {-Material characterization } \\
\text {-Ex-vivo microCT } \\
\text {-Mechanical test } \\
\text {-Histology } \\
\text {-Histomorphometry }\end{array}$ & $\begin{array}{l}\text { MicroCT: } \\
\uparrow \text { BV/TV, Tb.Th, Tb.N, Conn.D in } \\
\text { SrHA group } \\
\downarrow \text { Tb.Sp. in SrHA group } \\
\text { Histomorphometry: } \\
\uparrow \text { BAR and BIC } \% \text { in SrHA group } \\
\text { Mechanical test: } \\
\uparrow \text { push out force in SrHA group }\end{array}$ & [33] \\
\hline $\begin{array}{l}\text { Female Sprague } \\
\text { Dawley rats (three } \\
\text { months old) } \\
\text { Ovariectomy } \\
\text { OP assessment after } \\
12 \text { weeks: ex-vivo } \\
\text { microCT }\end{array}$ & $\begin{array}{l}70 \text { rats } \\
\text { Creation of femoral } \\
\text { cylindrical defects above the } \\
\text { distal epiphyseal growth plate }\end{array}$ & $\begin{array}{l}\text { Strontium enriched Calcium Phosphate } \\
\text { cement (SCPC) }(3 \mathrm{~mm} \times 5 \mathrm{~mm} \text { ) in the solid } \\
\text { phase combined with single-dose local } \\
\text { administration of BMP-2 (BSCPC) }\end{array}$ & $\begin{array}{l}\text { Group I: Control } \\
\text { Group II: CPC } \\
\text { Group III: SCPC } \\
\text { Group IV: BSCPC } \\
\text { Experimental times: } 8 \text { weeks } \\
\text {-Ex-vivo microCT } \\
\text {-Biomechanical testing } \\
\text {-Histology } \\
\end{array}$ & $\begin{array}{l}\text { MicroCT: } \\
\uparrow \text { BV/TV, Tb.Th, Tb.N, in BSCPC group } \\
\downarrow \text { Tb.Sp. in BSCPC group } \\
\text { Histology: } \\
\uparrow \text { new bone formation \% in BSCPC group } \\
\downarrow \text { remaining materials \% in BSCPC group } \\
\text { Mechanical test: } \\
\uparrow \text { Ultimate load in BSCPC group } \\
\end{array}$ & [34] \\
\hline $\begin{array}{l}\text { Female Sprague } \\
\text { Dawley rats (10 weeks } \\
\text { olds) } \\
\text { Ovariectomy + low } \\
\text { Ca-, P- and vit D3- } \\
\text { and soy- and } \\
\text { phytoestrogen-free } \\
\text { multi-deficient diet } \\
\text { (12 weeks) }\end{array}$ & $\begin{array}{l}45 \text { rats } \\
\text { After } 12 \text { weeks from OVX } \\
\text { surgery, creation of } 4 \mathrm{~mm} \\
\text { defect in the distal femur } \\
\text { metaphysis }\end{array}$ & $\begin{array}{l}\text { Strontium enriched Calcium Phosphate } \\
\text { Cement (SrCPC) in the solid phase } \\
\text { compared to CPC }\end{array}$ & $\begin{array}{l}\text { Group I: Control empty } \\
\text { Group II: CPC } \\
\text { Group III: SrCPC } \\
\text { Experimental times: } 6 \text { weeks } \\
\text {-TOF-SIMS analysis } \\
\text {-Histology } \\
\text {-Histomorphometry } \\
\text {-Immunohistochemistry }\end{array}$ & $\begin{array}{l}\text { Histomorphometry: } \\
\uparrow \mathrm{BV} / \mathrm{TV} \text { (defect region) in SrCPC vs. other } \\
\text { groups } \\
\uparrow \mathrm{BV} / \mathrm{TV} \text { (implant region) in SrCPC vs. } \\
\mathrm{CPC} \\
\uparrow \mathrm{Ma} / \mathrm{Tb} \text {.Ar (defect region) in SrCPC vs. } \\
\text { other groups } \\
\uparrow \mathrm{Ma} / \mathrm{Tb} \text {.Ar (implant region) in SrCPC vs. } \\
\text { CPC }\end{array}$ & [38] \\
\hline $\begin{array}{l}\text { Female Wistar rats } \\
\text { ( } 3 \text { months old) } \\
\text { Ovariectomy + low } \\
\text { calcium diet } \\
\text { ( } 6 \text { weeks) }\end{array}$ & $\begin{array}{l}20 \text { rats } \\
\text { After } 6 \text { weeks from OVX } \\
\text { surgery, bilaterally creation of } \\
\text { defects in femoral condyles } \\
(2.5 \mathrm{~mm} \times 5 \mathrm{~mm})\end{array}$ & $\begin{array}{l}\text { Calcium Phosphate Cement } \\
\text { (CPC)/Poly(DL-lactic-co-glycolic acid) } \\
\text { PLGA composite in comparison with } \\
\text { Alendronate enriched CPC/PLGA } \\
\text { composite in the liquid phase } \\
\text { (CPC/PLGA-ALN). }\end{array}$ & $\begin{array}{l}\text { Group I: CPC/PLGA-blank } \\
\text { Group II: CPC/PLGA-lowALN } \\
\text { Experimental times: } 4 \text { and } 12 \text { weeks } \\
\text {-Material characterization } \\
\text {-Bone dynamics analysis } \\
\text {-Ex vivo microCT } \\
\text {-Histology } \\
\text {-Histomorphometry }\end{array}$ & $\begin{array}{l}\text { Bone dynamics analysis: } \\
\uparrow \text { calcein green within ROI for } \\
\text { CPC/PLGA-blank vs. CPC/PLGA-lowALN } \\
\uparrow \text { calcein green in the eROI for } \\
\text { CPC/PLGA-lowALN vs CPC/PLGA-blank } \\
\text { Histomorphometry: } \\
\uparrow \text { bone formation within ROI from } 4 \\
\text { to } 12 \text { weeks for both CPC/PLGA-blank and } \\
\text { CPC/PLGA-lowALN } \\
\downarrow \text { bone formation over time in the ROI for } \\
\text { CPC/PLGA-blank } \\
\uparrow \text { bone formation over time for } \\
\text { CPC/PLGA-lowALN } \\
\downarrow \text { material remnants CPC/PLGA-blank } \\
\uparrow \text { bone at } 12 \text { weeks in the ROI for } \\
\text { CPC/PLGA-low ALN vs. } \\
\text { CPC/PLGA-blank }\end{array}$ & [40] \\
\hline
\end{tabular}


Table A1. Cont.

\begin{tabular}{|c|c|c|c|c|c|}
\hline Animal Model & $\begin{array}{c}\text { No. of Animals and Site of } \\
\text { Implant }\end{array}$ & $\begin{array}{l}\text { Materials Characteristics and } \\
\text { Functionalization }\end{array}$ & Experimental Set-up & Main Results & Ref. \\
\hline $\begin{array}{l}\text { Female Sprague } \\
\text { Dawley } \\
\text { rats ( } 3 \text { months old) } \\
\text { Ovariectomy }\end{array}$ & $\begin{array}{l}36 \text { rats } \\
\text { Bilateral critical-sized defect } \\
\text { in calvaria }(5 \mathrm{~mm} \varnothing)\end{array}$ & $\begin{array}{l}\text { CPC scaffold }(5 \mathrm{~mm} \times 3 \mathrm{~mm}) \text { loaded with } \\
\text { Icariin at concentrations of } 0,20,200 \text { or } \\
2000 \mu \mathrm{M} \text { (CPC-ICA) and lyophilized + } \\
\text { seeding with autologous BMSCs. }\end{array}$ & $\begin{array}{l}\text { Group I: CPC } \\
\text { Grou II: CPC/ICA-2000 } \\
\text { Group III: CPC/ ICA-ig } 5 \mathrm{~mm} \\
\text { Group IV: CPC/ICA-200 + ICA-ig } \\
\text { Experimental times: } 8 \text { weeks } \\
\text {-Serum dosage: Ca, Pi and ALP activity } \\
\text {-DEXA } \\
\text {-Biomechanical parameters } \\
\text {-Histology (with fluorescent labelling) } \\
\text {-Microfil perfusion }\end{array}$ & $\begin{array}{l}\text { Fluorescent labelling: } \\
\uparrow \text { fluorescent staining in CPC/ICA-2000 + } \\
\text { ICA-ig } \\
\text { Microfil perfusion: } \\
\uparrow \text { new vessels formation in CPC/ICA-2000 } \\
+ \text { ICA-ig } \\
\text { Histology: } \\
\uparrow \text { new bone \% in CPC/ICA-2000 + ICA-ig }\end{array}$ & [46] \\
\hline $\begin{array}{l}\text { Female Sprague- } \\
\text { Dawley rats (16 weeks } \\
\text { old) } \\
\text { Ovariectomy } \\
\text { After } 3 \text { months, OP } \\
\text { assessment }\end{array}$ & $\begin{array}{l}20 \text { rats } \\
\text { Bilateral critical-sized defect } \\
\text { in calvaria }(5 \mathrm{~mm} \varnothing)\end{array}$ & $\begin{array}{l}\text { Akermanite powders (Ca2MgSi2O7) were } \\
\text { synthesized by a sol-gel process, while } \\
\beta \text {-TCP powders synthesized by chemical } \\
\text { precipitation. Scaffolds were obtained } \\
(5 \times 3) \text { adopting polyethylene glycol (PEG) } \\
\text { particulates as porogens. }\end{array}$ & $\begin{array}{l}\text { Group I: } \beta \text {-TCP } \\
\text { Group II: Akermanite } \\
\text { Experimental times: } 8 \text { weeks } \\
\text {-Material characterization } \\
\text {-Ex vivo microCT } \\
\text {-Histology in PMMA } \\
\text {-Fluorescent labelling } \\
\text {-Gene expression }\end{array}$ & $\begin{array}{l}\text { Ex vivo microCT: } \\
\uparrow \text { BV/TV and Tb.Th in Akermanite group } \\
\text { Histology: } \\
\downarrow \text { Trap positivity in akermanite group } \\
\uparrow \text { Bone formation \% in akermanite group } \\
\uparrow \mathrm{MAR} \% \text { and fluorescence positivity in } \\
\text { akermanite group } \\
\text { Gene expression: } \\
\uparrow \text { RUNX2, OCN, OPG, TRA, CD31 } \\
\text { expression in akermanite group }\end{array}$ & [47] \\
\hline $\begin{array}{l}\text { Female } \\
\text { Sprague-Dawley rats } \\
\text { (8 months old) } \\
\text { Ovariectomy } \\
\text { After } 3 \text { months, OP } \\
\text { assessment }\end{array}$ & $\begin{array}{l}72 \text { rats } \\
\text { Creation of a bilateral defect } \\
\text { in distal end of the femur and } \\
\text { materials injection in the } \\
\text { femoral bone marrow space }\end{array}$ & $\begin{array}{l}\text { CaP particles enriched with trace elements } \\
\text { (te) (silicon, zinc and strontium ions) and } \\
\text { synthesized in simulated body fluid } \\
\text { (teCaP) }\end{array}$ & $\begin{array}{l}\text { Group I: Sham-Ctrl } \\
\text { Group II: Sham-CaP } \\
\text { Group III: Sham-teCaP } \\
\text { Group IV: OVX-Ctrl } \\
\text { Group V: OVX-CaP } \\
\text { Group VI: OVX-teCaP } \\
\text { Experimental times: } 2 \text { and } 3 \text { months } \\
\text {-DEXA } \\
\text {-Ex vivo microCT } \\
\text {-Biomechanical test } \\
\text {-Femoral bone element analysis } \\
\text {-Histology }\end{array}$ & $\begin{array}{l}\text { Ex vivo microCT: } \\
\uparrow \mathrm{BV} / \mathrm{TV}, \mathrm{BSA} / \mathrm{BV}, \mathrm{Tb} . \mathrm{Tn} \text {. in OVX-teCaP } \\
\text { gropus vs. other OVX groups } \\
\downarrow \text { Tb.Sp in OVX-teCaP gropus vs. other } \\
\text { OVX groups }\end{array}$ & [32] \\
\hline $\begin{array}{l}\text { Female } \\
\text { Sprague-Dawley rats } \\
\text { (3 months old) } \\
\text { Ovariectomy }\end{array}$ & $\begin{array}{l}36 \text { rats } \\
\text { After } 12 \text { weeks, creation of } \\
\text { defect in the proximal tibia. }\end{array}$ & $\begin{array}{l}\text { Titanium implants }(2 \mathrm{~mm} \times 6 \mathrm{~mm}) \text { coated } \\
\text { with } \mathrm{HA} \text { or } \mathrm{Zn} / \mathrm{Mg} / \mathrm{Sr} \text { enriched HA via } \\
\text { electrochemical deposition. }\end{array}$ & $\begin{array}{l}\text { Group I: HA coating } \\
\text { Group II: Zn-HA } \\
\text { Group III: Mg-HA } \\
\text { Group IV: Sr-HA } \\
\text { Experimental times: 4, 8, 12 weeks } \\
\text {-Material characterization } \\
\text {-Histology } \\
\text {-Histomorphometry }\end{array}$ & $\begin{array}{l}\text { Histomorphometry } \\
\uparrow \mathrm{BIC} \% \text { in Zn-HA vs. HA at } 4 \text { weeks } \\
\uparrow \mathrm{BIC} \% \text { in Sr-HA vs. HA at } 8 \text { and } 12 \text { weeks } \\
\uparrow \mathrm{BA} \% \text { in } \mathrm{Zn}-\mathrm{HA} \text { and SR-HA at } 8 \text { and } 12 \\
\text { weeks }\end{array}$ & [31] \\
\hline
\end{tabular}


Table A2. Data extraction from medium and large animal models (rabbit and sheep) research.

\begin{tabular}{|c|c|c|c|c|c|}
\hline Animal Model & $\begin{array}{c}\text { No. of Animals and Site of } \\
\text { Implant }\end{array}$ & Materials Characteristics and Functionalization & Experimental Set-up & Main Results & Ref. \\
\hline \multicolumn{6}{|c|}{ - } \\
\hline $\begin{array}{l}\text { New Zealand rabbits } \\
\text { ( } \sim 6 \text { months) } \\
\text { ovariectomized }+ \\
\text { methylprednisolone } \\
\text { injection for } 28 \mathrm{~d}\end{array}$ & $\begin{array}{l}30 \text { rabbits with defects created } \\
\text { in epiphysis of the right medial } \\
\text { tibia }(d=6 \mathrm{~mm}, \varnothing=3 \mathrm{~mm})\end{array}$ & $\begin{array}{l}\text { A composite material made of Calcium silicate } \\
\text { powder }\left(50 \mathrm{wt} \% \text { of } \mathrm{Ca}_{2} \mathrm{SiO}_{4} \text { and } 50 \mathrm{wt} \% \text { of } \mathrm{Ca}_{3} \mathrm{SiO}_{5}\right) \\
\text { Risedronate Calcium Phosphate Silicate Cements } \\
(\mathrm{RA}-\mathrm{CPSC}), 10 \mathrm{wt} \% \text { of monocalcium phosphate }(\mathrm{MCP}, \\
\mathrm{Ca}\left(\mathrm{H}_{2} \mathrm{PO}_{4}\right)_{2} \text { and } 0.5 \mathrm{wt} \% \text { or } 1.0 \mathrm{wt} \% \text { of risedronate } \\
\text { added into calcium silicate powder and } \\
\text { homogeneously mixed respectively. }\end{array}$ & $\begin{array}{l}\text { Group I: CPCS } \\
\text { Group II: RA-CPCS } 0.5 \% \\
\text { Group III: sham control } \\
\text { Experimental time: } 8 \text { weeks and } 10 \text { weeks } \\
\text {-X-ray semi-quantitative analysis } \\
\text {-CR array analysis }\end{array}$ & $\begin{array}{l}\text { X-ray } \\
\uparrow \text { Trabecular bone formation with X-ray in Group } \\
\text { II in comparison to Group I } \\
\text { after } 10 \text { weeks } \\
\text { PCR analysis } \\
\uparrow \text { up-regulation of genes in Group II in } \\
\text { comparison with Group I }\end{array}$ & [51] \\
\hline $\begin{array}{l}\text { Osteoporosis induced } \\
\text { with daily injected with } \\
\text { MPS hemisuccinate for } \\
4 \text { consecutive weeks } \\
\text { OP assessment: DEXA }\end{array}$ & $\begin{array}{l}\text { Lateral and medial defects } \\
(4 \mathrm{~mm} \text { diameter } 3-4 \mathrm{~mm} \text { deep) } \\
\text { in the both distal femoral } \\
\text { epiphysis }\end{array}$ & $\begin{array}{l}\text { Mesoporous silica (SBA15) } 100 \% \mathrm{SiO}_{2} \text { surface was } \\
\text { chemically modified with an organic modification of } \\
\text { silica walls with alkoxysilane, } n \text {-octyltriethoxysilane } \\
\text { (C8) and functionalized by soaking the mesoporous in } \\
\text { a solution of PTHrP (107-111) (osteostatin) in PBS }\end{array}$ & $\begin{array}{l}\text { Group I: SBA15 } \\
\text { Group II: PTHrP + SBA15 } \\
\text { Group III: SBA15 + C8 } \\
\text { Group IV: PTHrP + SBA15 + C8 } \\
\text { Experimental time: } 2 \text { weeks } \\
\text {-Histology and Immunohistochemistry }\end{array}$ & $\begin{array}{l}\text { No inflammation. } \\
\uparrow \text { staining for PCNA, Runx2, osteopontin, and/or } \\
\text { VEGF in OVX rabbits in both Group II and IV }\end{array}$ & [56] \\
\hline $\begin{array}{l}\text { Female ovariectomized } \\
\text { New Zealand rabbits } \\
(4.6 \pm 0.5 \mathrm{~kg})\end{array}$ & $\begin{array}{l}\text { After } 6 \text { months from } \\
\text { ovariectomy, in } 60 \text { rabbits, two } \\
\text { sub-periosteal mandibular } \\
\text { defects }(4 \mathrm{~mm} \times 5 \mathrm{~mm} \times \\
10 \mathrm{~mm})\end{array}$ & $\begin{array}{l}\text { Porous commercial HA (approximate porosity: } 40 \% \text {, } \\
\text { pore size: } 5-500 \mu \mathrm{m} \text {, compressive strength: } 15 \mathrm{MPa} \text { ) } \\
\text { was physically functionalized in surface with or } \\
\text { without } 10 \mu \mathrm{g} \text { of APN or } 100 \mu \mathrm{L} \text { Matrigel or } \\
\text { combination of both. }\end{array}$ & $\begin{array}{l}\text { Group I: APN + Matrigel + HA } \\
\text { Group II: APN + HA } \\
\text { Group III: Matrigel + HA } \\
\text { Group IV: HA } \\
\text { Experimental time: } 4 \text { weeks } \\
\text {-Histomorphometric analysis } \\
\text {-Micro-CT analysis } \\
\text {-Biomechanical analyses }\end{array}$ & $\begin{array}{l}\text { Histological analyses } \\
\downarrow \text { TRAP activity in Group I than other groups } \\
\uparrow \mathrm{NBV} \text { in Group I than the other groups } \\
\text { micro-CT analysis } \\
\uparrow \mathrm{BV} / \mathrm{TV} \text {, Conn.D, Tb.Th and Tb.N. in Group I than } \\
\text { other groups } \\
\downarrow \text { Tb.Sp in Group I than other groups } \\
\text { biomechanical analyses } \\
\uparrow \text { compressive strength and elastic modulus in } \\
\text { Group I than other groups }\end{array}$ & [57] \\
\hline $\begin{array}{l}\text { New Zealand OVX white } \\
\text { rabbits by administering } \\
\text { corticosteroids } \\
(1.5 \mathrm{mg} / \mathrm{kg} / \text { day) for } 28 \mathrm{~d}\end{array}$ & $\begin{array}{l}42 \text { rabbits with steel cancellous } \\
\text { bones screws }(\varnothing=4 \mathrm{~mm}, \\
h=10 \mathrm{~mm}) \text { implanted } \\
\text { bilaterally in } \\
\text { the medial femoral condyles } \\
\text { with or without augmentation } \\
\text { with HA and Fibronectin } \\
\text { loaded HA }\end{array}$ & $\begin{array}{l}\text { Physical incorporation of fibronectin in HA bulk } \\
\text { material by adding } 240 \mathrm{mg} \text { of HA to a solution } \\
\text { containing } 3.6 \mathrm{mg} \text { of fibronectin in PBS. }\end{array}$ & $\begin{array}{l}\text { Group I: augmentation with fibronectin } \\
\text { loaded HA } \\
\text { Group II: augmentation with HA } \\
\text { Group III: no augmentation } \\
\text { Experimental time: } 24 \mathrm{~h}, 48 \mathrm{~h} \text { and } 5 \text { dys } \\
\text {-Micro-CT analysis } \\
\text {-Histological analysis }\end{array}$ & $\begin{array}{l}\text { micro-CT analysis: } \\
\uparrow \text { Tb.Th in Group I in the area next the screw in } \\
\text { comparison with area far from the device } \\
\text { Histological analysis: } \\
\uparrow \text { cellularity at } 24 \mathrm{~h} \text { in Group I than the } \\
\text { other Groups }\end{array}$ & [58] \\
\hline $\begin{array}{l}\text { Female New Zealand } \\
\text { white rabbits (about } 2.5 \mathrm{~kg} \text { ) } \\
\text { ovariectomized } \\
\text { OP assessment after } 3 \\
\text { months in } 3 \text { healthy and } 3 \\
\text { OVX rabbits: microCT ex } \\
\text { vivo and histology }\end{array}$ & $\begin{array}{l}\text { After } 3 \text { months from } \\
\text { ovariectomy in } 43 \text { rabbits } \\
\text { implantation into the femoral } \\
\text { epiphysis }\end{array}$ & $\begin{array}{l}\text { TNT were immersed in supersaturated } \mathrm{Ca}(\mathrm{OH})_{2} \\
\text { solution, } \mathrm{Ca}\left(\mathrm{NO}_{3}\right)_{2} \cdot 4 \mathrm{H}_{2} \mathrm{O}(0.2 \mathrm{M}) \\
\text { and }\left(\mathrm{NH}_{4}\right)_{2} \mathrm{HPO}_{4}(0.2 \mathrm{M}) \text { solutions to create a coating } \\
\text { of } \mathrm{HA} \text {. TNT- } \mathrm{HA} \text { was subsequently functionalized } \\
\text { with Aln by immersion in Aln solution (physical } \\
\text { absorption). }\end{array}$ & $\begin{array}{l}\text { Group I: Ti } \\
\text { Group II: TNT } \\
\text { Group III: TNT-HA } \\
\text { Group IV: TNT-HA-Aln } \\
\text { Experimental time: } 12 \text { weeks } \\
\text {-X-rays } \\
\text {-Micro-CT } \\
\text {-Push out analysis } \\
\text {-Histological analyses }\end{array}$ & $\begin{array}{l}\text { X-rays and micro-CT: } \\
\text { no dislocation and inflammation occurred. } \\
\uparrow \text { BV/TV and Tb.Th in Group IV and III than } \\
\text { Group I and II } \\
\text { Push out: } \\
\uparrow \text { interfacial strength in Group IV than other } \\
\text { groups } \\
\uparrow \text { interfacial strength in Group III than Group I } \\
\text { and II } \\
\text { Histological analyses: } \\
\uparrow \text { Osteoid tissue in Group IV and III than } \\
\text { other Groups. }\end{array}$ & [52] \\
\hline
\end{tabular}


Table A2. Cont.

\begin{tabular}{|c|c|c|c|c|c|}
\hline Animal Model & $\begin{array}{c}\text { No. of Animals and Site of } \\
\text { Implant }\end{array}$ & Materials Characteristics and Functionalization & Experimental Set-up & Main Results & Ref. \\
\hline \multicolumn{6}{|c|}{ Rabbit } \\
\hline $\begin{array}{l}\text { New Zealand White } \\
\text { rabbits (6-month old; } \\
\text { ca. } 3 \mathrm{~kg} \text { ) ovariectomized }\end{array}$ & $\begin{array}{l}\text { Bilateral screw implantation in } \\
\text { distal femurs of } 16 \text { rabbits }\end{array}$ & $\begin{array}{l}\text { A composite material was realized creating } \\
\text { a Strontium enriched CPC in the solid phase and PCL } \\
\text { (poly e-caprolactone). }\end{array}$ & $\begin{array}{l}\text { Group I: PCL } \\
\text { Group II: CPC/PCL } \\
\text { Group III: Sr-CPC/PCL } \\
\text { Experimental time: } 24 \text { weeks } \\
\text {-Micro-CT analysis }\end{array}$ & $\begin{array}{l}\text { Micro-CT analysis: } \\
\uparrow \text { BV/TV, Tb.Th, Tb.N, connectivity density in } \\
\text { Group III than Group I } \\
\downarrow \text { Tb.Sp, SMI and total porosity in Group III than } \\
\text { Group I } \\
\downarrow \text { Tb.Sp in Group III than Group II }\end{array}$ & [53] \\
\hline $\begin{array}{l}\text { Female New Zealand } \\
\text { white rabbits ( }(90-100 \text { days } \\
\text { old, } 2-2.5 \mathrm{~kg}) \\
\text { ovariectomized }+ \text { MPS } \\
\text { sodium succinate } \\
\text { (1.0 } \mathrm{mg} / \mathrm{kg} / \text { day) injections } \\
\text { for } 4 \text { consecutive } \\
\text { months }\end{array}$ & $\begin{array}{l}\text { Bilateral implants in } 40 \text { rabbits: } \\
\text { two implants (2-mm diameter, } \\
\text { 10-mm depth) into each femur }\end{array}$ & $\begin{array}{l}\text { Ti-6Al-4V implants }(\varnothing 10 \times 2 \mathrm{~mm} \text { ) coated by means of } \\
\text { plasma-spray technique with } \mathrm{HA} \text { or } \mathrm{CaSiO}_{3} \text { or } \\
\text { zinc-modified calcium silicate }\left(\mathrm{Ca}_{2} \mathrm{ZnSi}_{2} \mathrm{O}_{7}\right) \text { at two } \\
\text { different } \mathrm{Zn} \text { contents (coating thickness about } 170 \mu \mathrm{m})\end{array}$ & $\begin{array}{l}\text { Group I: uncoated Ti-6Al-4V } \\
\text { Group II: } \mathrm{HA}_{-} \text {-coated Ti-6Al-4V, } \\
\text { Group III: } \mathrm{CaSiO}_{3} \text {-coated Ti-6Al-4V, } \\
\text { Group IV: } \mathrm{Ca}_{2} \mathrm{ZnSi}_{2} \mathrm{O}_{7} \text {-coated Ti-6Al-4V } \\
\text { (Zn-Ca 0.1) } \\
\text { Group V: } \mathrm{Ca}_{2} \mathrm{ZnSi}_{2} \mathrm{O}_{7} \text {-coated Ti-6Al-4V } \\
\text { (Zn-Ca 0.3) } \\
\text { Experimental time: } 4,8 \text { and } 12 \text { weeks } \\
\text {-Micro-CT analysis } \\
\text {-Histological analysis }\end{array}$ & $\begin{array}{l}\text { Micro-CT analysis: } \\
\text { all parameters } \uparrow \text { from } 4 \text { to } 8 \text { weeks } \\
\uparrow \text { highest values of all parameters in Group V than } \\
\text { all other Groups } \\
\text { Histological analysis: } \\
\text { No new bone in Group I } \\
\text { Small bone in Group II and III stating from } \\
4 \text { weeks } \\
\text { Strong new bone formation in Group IV and V } \\
\text { and improved osteointegration }\end{array}$ & [55] \\
\hline $\begin{array}{l}\text { California rabbits (eight } \\
\text { months old) ovariectomy } \\
+ \text { i.m. administration of } \\
\text { methylprednisolone } \\
(1 \mathrm{mg} / \mathrm{kg} / \text { day) for } 6 \text { weeks }\end{array}$ & $\begin{array}{l}30 \text { rabbits in which defect } \\
\text { created in the right }(5 \mathrm{~mm} \text { wide } \\
\text { and } 4 \mathrm{~mm}) \\
20 \mathrm{OVX} \text { and } 10 \text { healthy as } \\
\text { control }\end{array}$ & $\begin{array}{l}\text { A composite material of } \mathrm{HAP} / \mathrm{TCP}(23 \mathrm{wt} \% \mathrm{HAP} \text { and } \\
77 \mathrm{wt} \% \mathrm{TCP}) \text { granules with or without } 5 \% \mathrm{Sr} \\
\text { substitution. } \\
\text { Micro porosity and grain size of granules were in the } \\
\text { range from } 400 \text { to } 1 \mu \mathrm{m} \text {. The measured specific } \\
\text { surface area of the prepared granules was } 0.56 \mathrm{~m}^{2} / \mathrm{g} \text {. } \\
\text { Determined bulk density of the granules was } \\
1.28 \mathrm{~g} / \mathrm{cm}^{3} \text {. }\end{array}$ & $\begin{array}{l}\text { Group I: healthy bone }(10 \text { animals }) \\
\text { Group II: biphasic ceramic granules of } \\
\text { HAP/TCP } 30 / 70(7 \text { animals); } \\
\text { Group III: HAP/TCP }+5 \% \text { strontium } \\
\text { (7 animals) } \\
\text { Group IV: sham ( } 6 \text { animals) } \\
\text { Experimental time: } 12 \text { weeks } \\
\text {-Histomorphometry } \\
\text {-Immunohistochemistry }\end{array}$ & $\begin{array}{l}\text { Histomorphometry } \\
\uparrow \text { Greater mean trabecular area in Group I in } \\
\text { comparison to other groups } \\
\text { Immunohistochemistry } \\
\uparrow \text { increase of NFkB, OPG, OC, BMP } 2 / 4, \text { COL- } 1 \alpha \\
\text { and IL-1 in Group III in comparison to Group IV. }\end{array}$ & [54] \\
\hline \multicolumn{6}{|c|}{$\begin{array}{ll} & \text { Ovine Model } \\
\end{array}$} \\
\hline $\begin{array}{l}\text { Goat ovariectomy }+ \\
\text { low-calcium diet for } 3 \\
\text { mthsAdditional } 6 \text { mos for } \\
\text { OP development, } \\
\text { confirmed with BMD, } \\
\text { prior of surgery. }\end{array}$ & $\begin{array}{l}3 \text { Chinese goats with a total of } \\
24 \text { defects. } \\
\text { In each goats } 8 \text { cylindrical } \\
\text { defects with a diameter of } \\
8 \text { mm were created: } \\
-\quad 2 \text { in the left iliac crest; } \\
-\quad 2 \text { in the right iliac crest; } \\
-\quad 1 \text { in the left distal femur; } \\
-\quad 1 \text { in the third } \\
\quad \quad \text { lumbar vertebra; } \\
1 \text { in the fourth } \\
\text { lumbar vertebra; } \\
1 \text { in the fifth } \\
\text { lumbar vertebra. }\end{array}$ & $\begin{array}{l}\text { Nanocrystalline paste (Ostim }{ }^{\circledR} \text {, Germany) suspension } \\
\text { of pure HA in water prepared by a wet chemical } \\
\text { reaction. needle shaped HA crystals with a size of } \\
21 \mathrm{~nm} \text { in a-direction and of } 36 \mathrm{~nm} \text { in c-direction form } \\
\text { agglomerates. } \\
\text { Pure HA and an average crystallite size of } 18 \mathrm{~nm} \text {. } \\
\text { The atomic ratio of calcium: phosphorus is } 1.67 \text {. }\end{array}$ & $\begin{array}{l}\text { Group I: empty defects; } \\
\text { Group II: nanoparticulate hydroxyapatite; } \\
\text { Group III: nanoparticulatehydroxyapatite } \\
\text { + collagen type I. } \\
\text { Experimental time: } 6 \text { weeks } \\
\text {-High-resolution peripheral quantitative } \\
\text { computed tomography (HR-pQCT) } \\
\text {-Histomorphometry }\end{array}$ & $\begin{array}{l}\text { Osteoporosis confirmed by BMD (pQCT) at each } \\
\text { calcaneus (loss of } 24 \% \pm 2 \% \text { of the initial BMD). } \\
\text { HR-pQCT: } \\
\uparrow \text { BV/TV in Group II in comparison to Group I and } \\
\text { Group III within } 1 \mathrm{~mm} \text {; } \\
\downarrow \text { Tb.Sp Group II in comparison to Group I and } \\
\text { Group III within } 1 \mathrm{~mm} ; \\
\uparrow \text { Conn.D and Tb.N in Group III in comparison to } \\
\text { Group I and Group II. } \\
\text { Histomorphometry } \\
\uparrow \text { new bone formation (initial defect region) in } \\
\text { Group II and Group III in comparison to Group I }\end{array}$ & [65] \\
\hline
\end{tabular}


Table A2. Cont.

\begin{tabular}{|c|c|c|c|c|c|}
\hline Animal Model & $\begin{array}{l}\text { No. of Animals and Site of } \\
\text { Implant }\end{array}$ & Materials Characteristics and Functionalization & Experimental Set-up & Main Results & Ref. \\
\hline \multicolumn{6}{|c|}{$\begin{array}{l}\text { Ovine Model } \\
\end{array}$} \\
\hline $\begin{array}{l}\text { Skeletally mature female } \\
\text { sheeps ovariectomy }+ \\
\text { daily treatment for } \\
6 \text { months with MPS. } \\
4 \text { weeks before surgery } \\
\text { gradual reduction in GC } \\
\text { and } 1 \text { week before no GC } \\
\text { treatment. }\end{array}$ & $\begin{array}{l}10 \text { sheep. Defects }(10 \mathrm{~mm} \times \\
12 \mathrm{~mm}) \text { created laterally and } \\
\text { medially into the bone of distal } \\
\text { femurs bilaterally. } 4 \\
\text { implants/sheep: } 40 \text { implants. } \\
\text { Defects were filled with } \\
\text { cylindrical Ti plasma sprayed } \\
\text { pin. Around the Ti, the } \\
\text { circumferential gap of } 2 \mathrm{~mm} \\
\text { filled with one of the } \\
\text { experimental materials. }\end{array}$ & 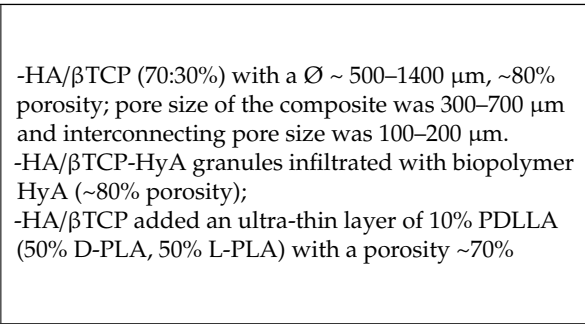 & 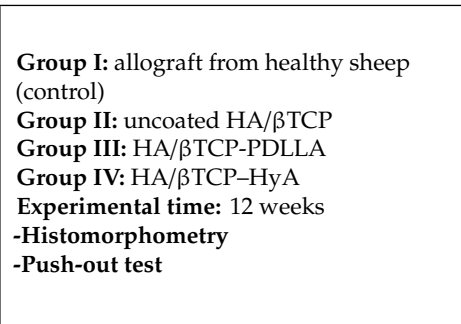 & $\begin{array}{l}\uparrow \text { bone marrow was statistically significantly } \\
\text { larger in the allograft group (ROI- } 1 \text { and ROI-2) } \\
\text { compared with the other groups } \\
\text { Histomorphometry } \\
\uparrow \mathrm{BV} / \mathrm{TV} \text { in Group I in comparison with Group II } \\
\uparrow \text { Bone marrow in Group I (ROI- } 1 \text { and ROI-2) } \\
\text { compared with the other Groups }\end{array}$ & [63] \\
\hline $\begin{array}{l}\text { Skeletally mature female } \\
\text { sheep ovariectomy }+ \\
\text { calcium deficient diet. } \\
\text { OP assessment after } \\
10 \text { months: microCT in } \\
\text { the hind limb }\end{array}$ & $\begin{array}{l}10 \text { sheep: } \\
8 \text { for the OVX group } \\
2 \text { as control CTR } \\
\text { Cylindrical implants }(12 \mathrm{~mm} \times \\
4 \mathrm{~mm}) \\
\text { cortical bone defect }(12 \mathrm{~mm} \times \\
4 \mathrm{~mm})\end{array}$ & $\begin{array}{l}10 \% \text { Strontium/Hydroxyapatite } \\
(\mathrm{SrHA})-\mathrm{Ca} 9 \mathrm{Sr}\left(\mathrm{PO}_{4}\right)_{6}(\mathrm{OH})_{2} \text { and Control } \\
\text { scaffold-Hydroxyapatite }(\mathrm{HA})-\mathrm{Ca}_{10}\left(\mathrm{PO}_{4}\right)_{6}(\mathrm{OH})_{2} \\
\text { synthesized by wet precipitation method } \\
\text { ADMSC isolated from subcutaneous fat pad of control } \\
\text { sheep used to functionalize SrHA (cSrHA) e HA } \\
\text { (cHA). }\end{array}$ & $\begin{array}{l}\text { Group I: SrHA } \\
\text { Group II: HA } \\
\text { Group III: cSrHA } \\
\text { Group IV: cHA } \\
\text { Experimental time: } 8 \text { weeks } \\
\text {-EDX } \\
\text {-Micro-computed tomography } \\
\text {-Histomorphometry }\end{array}$ & $\begin{array}{l}\text { Micro-computed tomography } \\
\uparrow \text { Bv/Tv in Group III than Group IV and Group I. } \\
\text { Histomorphometry: } \\
\uparrow \text { de novo bone formation in Group III, followed } \\
\text { by Group IV. Group I exhibited a RE ratio of } 0.24 \pm \\
0.04 \text { and Group II exhibited the least RE }\end{array}$ & [66] \\
\hline $\begin{array}{l}\text { Aged osteopenic sheep } \\
\text { (6-10 years) }\end{array}$ & 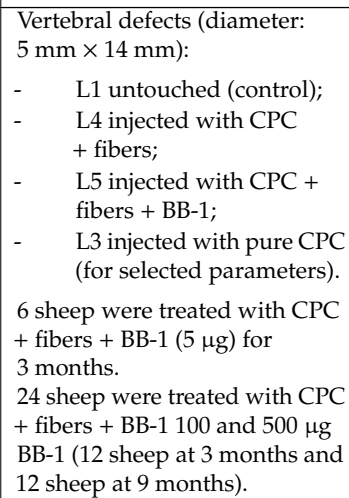 & $\begin{array}{l}\text { Powder of a commercially bone cement mixed with } \\
10 \% \text { fiber content of poly(l-lactide-co-glycolide, } \\
\text { PLGA) acid fibers (diameter of } 25 \mu \mathrm{m}) \\
\text { Lyophilized BB1 was dissolved in the liquid and } \\
\text { added to the cement reinforced powder. }\end{array}$ & $\begin{array}{l}\text { Group I: L1 untouched (control); } \\
\text { Group II: L4 injected with CPC + fibers; } \\
\text { Group III: L5 injected with CPC + fibers } \\
\text { +BB-1 (5, } 100 \text { and } 500 \mu \mathrm{\mu g}) \text {; } \\
\text { Group IV: L3 injected with pure CPC (only } \\
\text { for comparison with selected parameters) } \\
\text { Experimental time: } 12 \text { and } 36 \text { weeks } \\
\text {-Measurement of BMD } \\
\text {-Micro-CT } \\
\text {-Static and dynamic histomorphometry } \\
\text {-Biomechanical compressive strength }\end{array}$ & $\begin{array}{l}\uparrow \text { BMD in Group II and III vs Group I in all groups; } \\
\downarrow \text { BMD for Group II and III from } 12 \text { to } 36 \text { weeks, } \\
\text { with a significant difference for Group III at } 500 \mu \text { gg. } \\
\text { Micro-computed tomography } \\
\uparrow \text { BV/TV in Group II and III vs. Group I; } \\
\uparrow \text { BV/TV in Group III (500 } \mu \text { g) vs. Group II } \\
\uparrow \text { BV/TV TV in Group II and III vs. Group I in all } \\
\text { groups; } \\
\uparrow \text { BV/TV also in Group IV vs. Group I; } \\
\uparrow \text { BV/TV values for Group III vs. Group II and } \\
\text { Group IV for all doses of BB-1; } \\
\text { Significant differences between Group III and } \\
\text { Group II for } 5 \text { and } 100 \mu \mathrm{g} \text { BB-1 } 1 \text { at } 3 \text { months and for } \\
500 \mu \mathrm{g} \text { BB-1 at } 9 \text { months; } \\
\text { Significant differences between Group III and } \\
\text { Group IV for } 500 \mu \mathrm{g} \text { at } 3 \text { months, as well as for } 100 \\
\text { and } 500 \mu \mathrm{g} \text { BB- } 1 \text { at } 9 \text { months }\end{array}$ & [59] \\
\hline
\end{tabular}


Table A2. Cont.

\begin{tabular}{|c|c|c|c|c|c|}
\hline Animal Model & $\begin{array}{c}\text { No. of Animals and Site of } \\
\text { Implant }\end{array}$ & Materials Characteristics and Functionalization & Experimental Set-up & Main Results & Ref. \\
\hline \multicolumn{6}{|c|}{ Ovine Model } \\
\hline $\begin{array}{l}\text { Aged osteopenic } \\
\text { (6-9 years old) }\end{array}$ & $\begin{array}{l}\text { Forty four sheep in which } \\
\text { vertebral defects (diameter } \\
5 \mathrm{~mm} \times 14 \mathrm{~mm} \text { ) were created: } \\
-\quad \text { L1 untouched (control); } \\
-\quad \text { L4 injected with CPC } \\
\quad+\text { fibers; } \\
\quad \text { L5 injected with CPC + } \\
\quad \text { fibers + BMP-2; } \\
\text { BMP-2 at } 1,5,100 \text { and } 500 \mu \mathrm{g} \\
\text { with } n=5 \text { or } 6 \text {. }\end{array}$ & $\begin{array}{l}\text { CPC powder was mixed with } 10 \% \text { poly } \\
\text { (l-lactide-co-glycolide) acid (PLGA) fibers. } \\
\text { BMP-2 was dissolved and added to the } \\
\text { cement powder. }\end{array}$ & $\begin{array}{l}\text { Group I: L1 untouched (control); } \\
\text { Group II: L4 injected with CPC + fibers; } \\
\text { Group III: L5 injected with CPC + } \\
\text { fibers+BMP-2 (1, } 5 \text { and } 100 \mu \mathrm{\mu g}) ; \\
\text { Experimental time: } 12 \text { and } 36 \text { weeks } \\
\text {-Measurement of BMD } \\
\text {-Analysis of bone structure with } \\
\text {-Micro-CT } \\
\text {-Static and dynamic histomorphometry } \\
\text {-Biomechanical compressive strength }\end{array}$ & $\begin{array}{l}\uparrow \text { BMD in Group II and III vs. Group I at } 12 \text { and } 36 \\
\text { weeks; } \\
\text { Micro-computed tomography } \\
\uparrow \text { BV/TV in Group II and Group III vs. Group I at } \\
\text { all distances from the edge of the drill channel } \\
\uparrow \text { BV/TV between Group III and Group II at } 36 \\
\text { weeks for } 100 \mu \mathrm{g} \text { of BMP-2 } \\
\text { Static and dynamic histomorphometry: } \\
\uparrow \text { BV/TV in Group II and Group III vs. Group I; } \\
\uparrow \text { BV/TV in Group III vs. Group II for all doses of } \\
\text { BMP- } 2 \text {. } \\
\downarrow \text { effects from } 1 \text { and } 5 \text { to } 100 \text { and } 500 \mu \mathrm{gg} \text { BMP-2 at } \\
3 \text { months } \\
\uparrow \text { BV/TV, all 3-month and 9-month Tb.Th values } \\
\text { for Group III vs those for Group II for all doses of } \\
\text { BMP-2 } \\
\downarrow \text { Tb.N in Group II and III vs Group I in all groups }\end{array}$ & [60] \\
\hline $\begin{array}{l}\text { Sheep (4 years old) } \\
\text { ovariectomy }+ \\
\text { low-calcium diet }+ \\
\text { corticosteroids } \\
\text { administration }(500 \mathrm{mg} \\
\text { MPS via i.m. injection } \\
\text { every } 3 \text { weeks) }\end{array}$ & $\begin{array}{l}6 \text { sheep with } 6 \text { cylindrical } \\
\text { defects each }(10 \mathrm{~mm} \times 13 \mathrm{~mm}) \\
\text { created in the cancellous bone } \\
\text { after } 6 \text { months of: } \\
-\quad \text { proximal tibia epiphysis; } \\
-\quad \text { femur medial epicondyle; } \\
-\quad \text { humerus } \\
\quad \text { greater tuberosity }\end{array}$ & $\begin{array}{l}\mathrm{Ti}_{6} \mathrm{Al}_{4} \mathrm{~V} \text { ELI cylinders }(1 \mathrm{~cm} \times 1 \mathrm{~cm} \text { ) with a } \\
\text { macroporous structures obtained with EBM technique } \\
\text { (pores of } 2 \mathrm{~mm} \varnothing \text { and wall thickness } 700-800 \mu \mathrm{m}) . \mathrm{Si} \\
\text { enriched } \mathrm{HA} \text { coating were realized (Si-HA) followed } \\
\text { by a dip-coating process and adsorption and } \\
\text { immobilization of VEGF by means a non-covalent } \\
\text { binding with } 5 \mu \mathrm{g} / \mathrm{mL} \text { of VEGF-A. }\end{array}$ & $\begin{array}{l}\text { Group I: } \mathrm{Ti}_{6} \mathrm{Al}_{4} \mathrm{~V}-\mathrm{ELI}(\mathrm{Ti}) \\
\text { Group II: } \mathrm{Ti}_{6} \mathrm{Al}_{4} \mathrm{~V} \text {-ELI + adsorbed VEGF } \\
\text { (Ti-VEGF) } \\
\text { Group III: } \mathrm{Ti}_{6} \mathrm{Al}_{4} \mathrm{~V} \text {-ELI + coated with } \\
\mathrm{Si-HA} \text { (Ti@SiHA) } \\
\text { Group IV: } \mathrm{Ti}_{6} \mathrm{Al} \mathrm{Al}_{4} \mathrm{~V}-\mathrm{ELI}+\text { coated with } \\
\mathrm{Si-HA} \text { and adsorbed VEGF } \\
\text { (Ti@SiHA-VEGF) } \\
\text { Experimental time: } 12 \text { weeks } \\
\text {-Physico-chemical characterization } \\
\text {-Histomorphometry }\end{array}$ & $\begin{array}{l}\text { Histomorphometry } \\
\uparrow \text { Bone formation in Group IV in comparison with } \\
\text { other Groups } \\
\uparrow \text { Vessel formation in Group IV in comparison } \\
\text { with Group III }\end{array}$ & [64] \\
\hline $\begin{array}{l}\text { Sheep }(4 \text { years old) } \\
\text { ovariectomy }+ \text { low } \\
\text { calcium and low vitamin } \\
\text { D diet }+ \text { corticosteroids } \\
\text { administration }(500 \mathrm{mg} \\
\text { MPS via i.m. injection } \\
\text { every } 3 \text { weeks starting } 2 \\
\text { weeks post-OVX) } \\
\text { OP assessment after } 4 \\
\text { months: DEXA }\end{array}$ & $\begin{array}{l}\text { Six sheep in which } 2.0 \mathrm{~cm} \\
\text { diameter defect was created in } \\
\text { lumbar vertebrae L2 and L4. } \\
\text { Knitted OptiMesh sac was } \\
\text { inserted into the vertebral } \\
\text { defect. } \\
\text { rhNELL-1 was implanted at } \\
0.09 \mathrm{mg} \text { in } \mathrm{L} 2 \text { and at } 2.25 \mathrm{mg} \text { in } \\
\mathrm{L} 4(n=3 \text { sheep). Control } \\
\text { materials were implanted in the } \\
3 \text { remaining sheep. }\end{array}$ & $\begin{array}{l}\text { Control materials: hyaluronic acid }(\mathrm{HA}) \text { and } \\
\text { hydroxyapatite-coated } \beta \text {-tricalcium phosphate } \\
\text { ( } \beta \text {-TCP with granule size: } 50 \mu \mathrm{m}, \text { pore size: } 10 \mu \mathrm{m}, \\
\text { mixed with } 500 \mu \mathrm{m} \text { hydroxyapatite). } \\
\text { Treatment materials: } \\
\text { rhNELL-1 protein lyophilized onto b-TCP mixed into } \\
\text { the HA, for protein release } \\
\text { at two doses }(0.9 \text { and } 2.25 \mathrm{mg})\end{array}$ & $\begin{array}{l}\text { Group I: control (HA and } \beta \text {-TCP) } \\
\text { Group II: HA/ } \beta \text {-TCP + rhNELL-1 } 0.09 \mathrm{mg} \\
\text { Group III: HA/ } \beta \text {-TCP + rhNELL-1 } 2.25 \mathrm{mg} \\
\text { Experimental time: } 12 \text { weeks } \\
\text {-Measurement of BMD } \\
\text {-MicroCT } \\
\text {-Histomorphometry }\end{array}$ & $\begin{array}{l}\text { Measurement of BMD } \\
\uparrow \text { BMD in Group II and Group III vs. Group I } \\
\text { Micro-computed tomography } \\
\uparrow \text { BV/TV, Tb.N and Tb.Sp in Group II and Group } \\
\text { III vs. Group I } \\
\text { Histomorphometry: } \\
\uparrow \text { endocortical bone formation (Ct. Wi), Tb. Area } \\
\text { and Tb. N in Group II and Group III vs. Group I } \\
\downarrow \text { Tb.Sp. in Group II and Group III dose } \\
\text { dependent vs. Group I } \\
\uparrow \text { Ob. N significantly increased in Group III; } \\
\downarrow \text { Oc. N significant decrease in a dose manner in } \\
\text { Group II and Group III. }\end{array}$ & [61] \\
\hline $\begin{array}{l}\text { Sheep ovariectomized OP } \\
\text { assessment: sampling of } \\
\text { Iliac crest biopsy the time } \\
\text { of ovariectomy and } 6 \\
\text { months later during the } \\
\text { lumbar procedure }\end{array}$ & $\begin{array}{l}\text { Twelve adult sheep ( } 6 \\
\text { ovariectomized and } 6 \text { healthy } \\
\text { as control) with lumbar } \\
\text { vertebral bodies defects ( } 8 \mathrm{~mm} \\
\text { high } \times 10 \mathrm{~mm} \text { deep } 20 \mathrm{~mm} \\
\text { long), created into the } \mathrm{L} 3 \text { and } \\
\text { L4 vertebral bodies }\end{array}$ & $\begin{array}{l}\text { Alendronate enriched Calcium Deficient Apatite } \\
\text { (CDA) in the solid phase. }\end{array}$ & $\begin{array}{l}\text { Group I: CDA in L3 } \\
\text { Group II: Al-CDA in L4 } \\
\text { Group III: no surger } \\
\text { Experimental time: } 12 \text { weeks } \\
\text {-MicroCT }\end{array}$ & $\begin{array}{l}\text { Micro-computed tomography } \\
\uparrow \text { BV/TV in Group II vs. Group III } \\
\uparrow \text { BV/TV (+6.8\%) and TbTh }(+10.5 \%) \text { until } 1.2 \mathrm{~mm} \\
\text { and TbSp until } 0.8 \mathrm{~mm} \text { from the implant in Group } \\
\text { II vs. Group I. } \\
\uparrow \text { TbN and TbPf in Group II. } \\
\uparrow \text { cortical thickness (+43\%) in vertebrae after } \\
\text { implantation in Group II vs. Group I. }\end{array}$ & [62] \\
\hline
\end{tabular}


Table A3. Data extraction from clinical studies.

\begin{tabular}{|c|c|c|c|c|c|c|c|}
\hline $\begin{array}{l}\text { Enrolled Patients } \\
\text { and Pathology }\end{array}$ & Type of Trial & $\begin{array}{l}\text { Anatomical Site and } \\
\text { Type of Prosthesis }\end{array}$ & Aim & $\begin{array}{c}\text { Patient Groups } \\
\text { (Analyzed Patient } \\
\text { Number) } \\
\end{array}$ & $\begin{array}{c}\text { Quantitative } \\
\text { Measurements }\end{array}$ & Main Results & Ref. \\
\hline 39 with OA & Prospective study & $\begin{array}{l}\text { Hip hydroxyapatite } \\
\text { stem implant with } \\
\text { RSA-markers. Ceramic } \\
\text { heads and liners were } \\
\text { made of } \mathrm{Al}_{2} \mathrm{O}_{3}\end{array}$ & $\begin{array}{l}\text { To determine if low BMD } \\
\text { (OP and osteopenic } \\
\text { patients) affects primary } \\
\text { hip implant stability } \\
\text { assessed by RSA }\end{array}$ & $\begin{array}{l}\text { 1) normal BMD }(12 \mathrm{pt}) \\
\text { 2) low BMD }(27: 22 \\
\text { osteopenic and } 5 \\
\text { osteoporotic })\end{array}$ & $\begin{array}{l}\text { RSA at } 7 \text { days (baseline) } \\
\text { and } 3,6,12 \text { and } 24 \\
\text { months, } \\
\text { Harris hip and } \\
\text { WOMAC scores }\end{array}$ & $\begin{array}{l}\text { In pts with low BMD higher significant translation } \\
\text { at } 3 \text { months than those with normal BMD. } \\
\text { Patients with low BMD had a } 4 \% \text { probability of } \\
\text { osseointegration at } 3 \text { months, as compared to a } \\
50 \% \text { probability in patients with normal BMD. }\end{array}$ & [67] \\
\hline $\begin{array}{l}85 \text { with instable } \\
\text { intertrochanteric } \\
\text { fractures and OP }\end{array}$ & $\begin{array}{l}\text { Retrospective } \\
\text { cohort study }\end{array}$ & $\begin{array}{l}\text { Bipolar } \\
\text { hemiarthroplasty ( } 57 \\
\text { hips) with fully } \\
\text { HA-coated long-stem } \\
\text { titanium alloy } \\
\text { prosthesis }\end{array}$ & $\begin{array}{l}\text { To determine clinical and } \\
\text { radiologic results of } \\
\text { cementless } \\
\text { hemiarthroplasty using a } \\
\text { fully HA-coated long } \\
\text { stem in unstable inter- } \\
\text { trochanteric fractures of } \\
\text { patients with OP }\end{array}$ & $\begin{array}{l}87 \text { cementless bipolar } \\
\text { hemiarthroplasties ( } 85 \\
\text { pt) }\end{array}$ & $\begin{array}{l}\text { Koval's, Merle } \\
\text { d'Aubigne and Postel } \\
\text { scores (at } 6 \text { weeks, at } 3, \\
6,9 \text { and } 12 \text { months and } \\
\text { every year thereafter) } \\
\text { X-rays morphometry; }\end{array}$ & $\begin{array}{l}\text { Koval's score: } 28.3 \% \text { patients were independent, } \\
11.7 \% \text { walked with canes, } 16.7 \% \text { with crutches or } \\
\text { walkers, } 18.3 \% \text { used household ambulators and } \\
21.7 \% \text { pts became non functional ambulatory at } \\
\text { the final follow-up. } \\
\text { Merled'Aubigne and Postel: mean score was } 14.7 \\
\text { points. } \\
\text { Cortical porosis in } 37.5 \% \text {; acetabular erosion in } \\
4.2 \% \text {; heterotopic ossification in } 6.3 \% \text {; no } \\
\text { subsidence, no failure of leg length equalization, } \\
\text { no osteolysis. }\end{array}$ & [68] \\
\hline $\begin{array}{l}22 \text { requiring } \\
\text { bilateral pedicle } \\
\text { screw fixation for } \\
\text { lumbar fusion } \\
\text { surgery }\end{array}$ & $\begin{array}{l}\text { Prospective } \\
\text { within-patient, } \\
\text { left-right } \\
\text { comparative study }\end{array}$ & $\begin{array}{l}\text { Posterior pedicle screw } \\
\text { fixation with HA sticks } \\
(100 \% \text { pure HA granules } \\
\text { with } 3 \mathrm{~d} \text {. Interconnected } \\
\text { porous }(70 \% \text { porosity) } \\
\text { structure of } 100-300 \mu \mathrm{m}) \\
\text { and interbody fusion }\end{array}$ & $\begin{array}{l}\text { To evaluate the efficacy of } \\
\text { HA stick augmentation on } \\
\text { enhancing initial pedicle } \\
\text { screw fixation strength, in } \\
\text { OP and nonosteoporotic } \\
\text { pts }\end{array}$ & $\begin{array}{l}\text { 1) nonosteoporotic } \\
\text { group with HA sticks } \\
\text { and conventional screws } \\
\text { 2) osteoporotic group } \\
\text { with HA sticks and } \\
\text { conventional screws }\end{array}$ & $\begin{array}{l}\text { Torque measurement at } \\
\text { surgery } \\
\text { VAS, ODI and Short } \\
\text { Form-36 Health Survey } \\
\text { (preop and at } 1 \text { year) } \\
\text { CT scan (at } 1 \text { year) } \\
\text { X-rays (post op and at 6, } \\
12 \text { and } 24 \text { months) }\end{array}$ & $\begin{array}{l}\text { Torque: pedicle screws with HA stick insertion } \\
\text { significantly higher values than that without HA } \\
\text { insertion in both OP and non OP pts with } \\
\text { significant higher values in the non OP group then } \\
\text { in the OP one. Differences in bone sclerosis } \\
\text { between HA and control groups, regardless of the } \\
\text { presence of osteoporosis }\end{array}$ & [71] \\
\hline $\begin{array}{l}34 \text { with } \\
\text { spondylolisthesis } \\
\text { grade I or II and } \\
\text { osteoporosis }\end{array}$ & $\begin{array}{l}\text { Retrospective } \\
\text { cohort study }\end{array}$ & $\begin{array}{l}\text { Spinal transforaminal } \\
\text { lumbar interbody fusion } \\
\text { (L4-L5) with } \\
\text { PEEK cages with or } \\
\text { without screw } \\
\text { augmentation with HA } \\
\text { cement }\end{array}$ & $\begin{array}{l}\text { To determine the efficacy } \\
\text { of HA cement for screw } \\
\text { augmentation in } \\
\text { osteoporotic patients }\end{array}$ & $\begin{array}{l}\text { 1) a screw augmentation } \\
\text { group with HA cement } \\
\text { (not reported) } \\
\text { 2) a non augmented } \\
\text { group (not reported) }\end{array}$ & $\begin{array}{l}\text { X-rays morphometry } \\
\text { (at day 1, at } 3 \text { months, at } \\
1 \text { and } 2 \text { years), } \\
\text { VAS (post-op, } 3 \text { months } \\
\text { and } 2 \text { years) }\end{array}$ & $\begin{array}{l}\text { 1) } 1 \text { patient had revision surgery for the removal } \\
\text { of a drainage tube that was tightly anchored to the } \\
\text { fascia } \\
\text { 2) } 1 \text { patient had revision surgery because of } \\
\text { subcutaneous fluid collection; significant increases } \\
\text { in SL, SA and DH; }\end{array}$ & [70] \\
\hline $\begin{array}{l}11 \text { with painful OP } \\
\text { vertebral fractures }\end{array}$ & $\begin{array}{l}\text { Retrospective } \\
\text { cohort study }\end{array}$ & $\begin{array}{l}\text { Kyphoplasty using CaP } \\
\text { cement }\end{array}$ & $\begin{array}{l}\text { To investigate long-term } \\
\text { radio-morphologic } \\
\text { features of intraosseous } \\
\text { and extraosseous linkages } \\
\text { of CaP implants }\end{array}$ & $\begin{array}{l}\text { twenty-four } \\
\text { kyphoplasty procedures } \\
\text { (11 pt) }\end{array}$ & $\begin{array}{l}\text { X-rays morphometry } \\
\text { CT scan } \\
\text { VAS and EVOS scores } \\
\text { (1 week and } 1,2 \text { and } 3 \\
\text { years) }\end{array}$ & $\begin{array}{l}\text { Moderate reduction of } 6.6 \% \text { per year of the } \\
\text { intraosseous CaP volume. } \\
\uparrow \text { postoperative vertebral height and sagittal index } \\
\text { VAS improved significantly } 2 \text { years after } \\
\text { implantation and EVOS from } 1 \text { year }\end{array}$ & [69] \\
\hline
\end{tabular}




\section{References}

1. Mavrogenis, A.F.; Dimitriou, R.; Parvizi, J.; Babis, G.C. Biology of implant osseointegration. J. Musculoskelet. Neuronal Interact. 2009, 9, 61-71.

2. Fini, M.; Carpi, A.; Borsari, V.; Tschon, M.; Nicolini, A.; Sartori, M.; Mechanick, J.; Giardino, R. Bone remodeling, humoral networks and smart biomaterial technology for osteoporosis. Fron. Biosci. (Sch. Ed.) 2010, 2, 68-82. [CrossRef]

3. Smeets, R.; Stadlinger, B.; Schwarz, F.; Beck-Broichsitter, B.; Jung, O.; Precht, C.; Kloss, F.; Gröbe, A.; Heiland, M.; Ebker, T. Impact of dental implant surface modifications on osseointegration. BioMed Res. Int. 2016, 2016, 6285620. [CrossRef] [PubMed]

4. Treccani, L.; Yvonne Klein, T.; Meder, F.; Pardun, K.; Rezwan, K. Functionalized ceramics for biomedical, biotechnological and environmental applications. Acta Biomater. 2013, 9, 7115-7150. [CrossRef]

5. Li, L.; Lu, H.; Zhao, Y.; Luo, J.; Yang, L.; Liu, W.; He, Q. Functionalized cell-free scaffolds for bone defect repair inspired by self-healing of bone fractures: A review and new perspectives. Mater. Sci. Eng. C Mater. Biol. Appl. 2019, 98, 1241-1251. [CrossRef]

6. Fini, M.; Salamanna, F.; Veronesi, F.; Torricelli, P.; Nicolini, A.; Benedicenti, S.; Carpi, A.; Giavaresi, G. Role of obesity, alcohol and smoking on bone health. Fron. Biosci. (Elite Ed.) 2012, 4, 2586-2606.

7. Fini, M.; Giavaresi, G.; Torricelli, P.; Borsari, V.; Giardino, R.; Nicolini, A.; Carpi, A. Osteoporosis and biomaterial osteointegration. Biomed. Pharmacother. 2004, 58, 487-493. [CrossRef] [PubMed]

8. Fini, M.; Giavaresi, G.; Salamanna, F.; Veronesi, F.; Martini, L.; De Mattei, M.; Tschon, M. Harmful lifestyles on orthopedic implantation surgery: A descriptive review on alcohol and tobacco use. J. Bone Min. Metab. 2011, 29, 633-644. [CrossRef] [PubMed]

9. Akkawi, I.; Zmerly, H. Osteoporosis: Current concepts. Joints 2018, 6, 122-127. [CrossRef] [PubMed]

10. Reginster, J.Y.; Burlet, N. Osteoporosis: A still increasing prevalence. Bone 2006, 38, S4-S9. [CrossRef]

11. Cawthon, P.M. Gender differences in osteoporosis and fractures. Clin. Orthop. Relat. Res. 2011, 469, $1900-1905$. [CrossRef]

12. Tomé-Bermejo, F.; Piñera, A.R.; Alvarez, L. Osteoporosis and the management of spinal degenerative disease (II). Arch. Bone Jt. Surg. 2017, 5, 363-374. [PubMed]

13. Dereka, X.; Calciolari, E.; Donos, N.; Mardas, N. Osseointegration in osteoporotic-like condition: A systematic review of preclinical studies. J. Periodontal Res. 2018, 53, 933-940. [CrossRef] [PubMed]

14. Alghamdi, H.S.; Cuijpers, V.M.; Wolke, J.G.; van den Beucken, J.J.; Jansen, J.A. Calcium-phosphate-coated oral implants promote osseointegration in osteoporosis. J. Dent. Res. 2013, 92, 982-988. [CrossRef]

15. Libicher, M.; Hillmeier, J.; Liegibel, U.; Sommer, U.; Pyerin, W.; Vetter, M.; Meinzer, H.P.; Grafe, I.; Meeder, P.; Nöldge, G.; Nawroth, P.; et al. Osseous integration of calcium phosphate in osteoporotic vertebral fractures after kyphoplasty: Initial results from a clinical and experimental pilot study. Osteoporos. Int. 2006, 17, 1208-1215. [CrossRef]

16. Alghamdi, H.S.; Junker, R.; Bronkhorst, E.M.; Jansen, J.A. Bone regeneration related to calcium phosphate-coated implants in osteoporotic animal models: A meta-analysis. Tissue Eng. Part B Rev. 2012, 18, 383-395. [CrossRef] [PubMed]

17. Daculsi, G.; Laboux, O.; Malard, O.; Weiss, P. Current state of the art of biphasic calcium phosphate bioceramics. J. Mater. Sci. Mater. Med. 2003, 14, 195-200. [CrossRef] [PubMed]

18. Davies, J. Understanding peri-implant endosseous healing. J. Dent. Educ. 2003, 67, 932-949.

19. McEntire, B.J.; Bal, B.S.; Rahaman, M.N.; Chevalier, J.; Pezzotti, G. Ceramics and ceramic coatings in orthopaedics. J. Eur. Ceram. Soc. 2015, 35, 4327-4369. [CrossRef]

20. Moher, D.; Shamseer, L.; Clarke, M.; Ghersi, D.; Liberati, A.; Petticrew, M.; Shekelle, P.; Stewart, L.A. PRISMA-P Group. Preferred reporting items for systematic review and meta-analysis protocols (PRISMA-P) 2015 statement. Syst. Rev. 2015, 4, 1-9. [CrossRef]

21. Kauschke, V.; Schneider, M.; Jauch, A.; Schumacher, M.; Kampschulte, M.; Rohnke, M.; Henss, A.; Bamberg, C.; Trinkaus, K.; Gelinsky, M.; et al. Effects of a pasty bone cement containing brain-derived neurotrophic factor-functionalized mesoporous bioactive glass particles on metaphyseal healing in a new murine osteoporotic fracture model. Int. J. Mol. Sci. 2018, 19, 3531. [CrossRef] 
22. Alghamdi, H.S.; Bosco, R.; Both, S.K.; Iafisco, M.; Leeuwenburgh, S.C.; Jansen, J.A.; van den Beucken, J.J. Synergistic effects of bisphosphonate and calcium phosphate nanoparticles on peri-implant bone responses in osteoporotic rats. Biomaterials 2014, 35, 5482-5490. [CrossRef]

23. Pyo, S.W.; Kim, Y.M.; Kim, C.S.; Lee, I.S.; Park, J.U. Bone formation on biomimetic calcium phosphate- coated and zolendronate- immobilized titanium implants in osteoporotic rat tibiae. Int. J. Oral Maxillofac. Implants 2014, 29, 478-484. [CrossRef]

24. Kettenberger, U.; Luginbuehl, V.; Procter, P.; Pioletti, D.P. In vitro and in vivo investigation of bisphosphonate-loaded hydroxyapatite particles for peri-implant bone augmentation. J. Tissue Eng. Regen. Med. 2017, 11, 1974-1985. [CrossRef]

25. Li, X.; Li, Y.; Peng, S.; Ye, B.; Lin, W.; Hu, J. Effect of zinc ions on improving implant fixation in osteoporotic bone. Connect. Tissue Res. 2013, 54, 290-296. [CrossRef]

26. Li, X.; Li, Y.; Liao, Y.; Li, J.; Zhang, L.; Hu, J. The effect of magnesium-incorporated hydroxyapatite coating on titanium implant fixation in ovariectomized rats. Int. J. Oral Maxillofac. Implants 2014, 29, 196-202. [CrossRef] [PubMed]

27. Li, Y.; Luo, E.; Zhu, S.; Li, J.; Zhang, L.; Hu, J. Cancellous bone response to strontium-doped hydroxyapatite in osteoporotic rats. J. Appl. Biomater. Funct. Mater. 2015, 13, 28-34. [CrossRef]

28. Li, Y.; Shui, X.; Zhang, L.; Hu, J. Cancellous bone healing around strontium-doped hydroxyapatite in osteoporotic rats previously treated with zoledronic acid. J. Biomed. Mater. Res. B Appl. Biomater. 2016, 104, 476-481. [CrossRef]

29. Tao, Z.S.; Bai, B.L.; He, X.W.; Liu, W.; Li, H.; Zhou, Q.; Sun, T.; Huang, Z.L.; Tu, K.K.; Lv, Y.X.; et al. A comparative study of strontium-substituted hydroxyapatite coating on implant's osseointegration for osteopenic rats. Med. Biol. Eng. Comput. 2016, 54, 1959-1968. [CrossRef] [PubMed]

30. Tao, Z.S.; Zhou, W.S.; Qiang, Z.; Tu, K.K.; Huang, Z.L.; Xu, H.M.; Sun, T.; Lv, Y.X.; Cui, W.; Yang, L. Intermittent administration of human parathyroid hormone (1-34) increases fixation of strontium-doped hydroxyapatite coating titanium implants via electrochemical deposition in ovariectomized rat femur. J. Biomater. Appl. 2016, 30, 952-960. [CrossRef]

31. Zhang, J.; Liu, L.; Zhao, S.; Wang, H.; Yang, G. Characterization and in vivo evaluation of trace element-loaded implant surfaces in ovariectomized rats. Int. J. Oral Maxillofac. Implants 2015, 30, 1105-1112. [CrossRef] [PubMed]

32. Yang, X.; Xu, S.; Chen, X.; He, D.; Ke, X.; Zhang, L.; Yang, G.; Liu, A.; Mou, X.; Xia, W.; et al. Intra-bone marrow injection of trace elements co-doped calcium phosphate microparticles for the treatment of osteoporotic rat. J. Biomed. Mater. Res. A 2017, 105, 1422-1432. [CrossRef] [PubMed]

33. Tao, Z.S.; Zhou, W.S.; He, X.W.; Liu, W.; Bai, B.L.; Zhou, Q.; Huang, Z.L.; Tu, K.K.; Li, H.; Sun, T.; et al. A comparative study of zinc, magnesium, strontium-incorporated hydroxyapatite-coated titanium implants for osseointegration of osteopenic rats. Mater. Sci. Eng. C Mater. Biol. Appl. 2016, 62, 226-232. [CrossRef] [PubMed]

34. Tao, Z.; Zhou, W.; Jiang, Y.; Wu, X.; Xu, Z.; Yang, M.; Xie, J. Effects of strontium-modified calcium phosphate cement combined with bone morphogenetic protein-2 on osteoporotic bone defects healing in rats. J. Biomater. Appl. 2018, 33, 3-10. [CrossRef] [PubMed]

35. Baier, M.; Staudt, P.; Klein, R.; Sommer, U.; Wenz, R.; Grafe, I.; Meeder, P.J.; Nawroth, P.P.; Kasperk, C. Strontium enhances osseointegration of calcium phosphate cement: A histomorphometric pilot study in ovariectomized rats. J. Orthop. Surg. Res. 2013, 8, 16. [CrossRef] [PubMed]

36. Cardemil, C.; Elgali, I.; Xia, W.; Emanuelsson, L.; Norlindh, B.; Omar, O.; Thomsen, P. Strontium-doped calcium phosphate and hydroxyapatite granules promote different inflammatory and bone remodelling responses in normal and ovariectomised rats. PLoS ONE. 2013, 8, e84932. [CrossRef] [PubMed]

37. Chandran, S.; Babu, S.S.; Vs, H.K.; Varma, H.K.; John, A. Osteogenic efficacy of strontium hydroxyapatite micro-granules in osteoporotic rat model. J. Biomater. Appl. 2016, 31, 499-509. [CrossRef] [PubMed]

38. Thormann, U.; Ray, S.; Sommer, U.; Elkhassawna, T.; Rehling, T.; Hundgeburth, M.; Henß, A.; Rohnke, M.; Janek, J.; Lips, K.S.; et al. Bone formation induced by strontium modified calcium phosphate cement in critical-size metaphyseal fracture defects in ovariectomized rats. Biomaterials 2013, 34, 8589-8598. [CrossRef] [PubMed] 
39. Cheng, C.; Alt, V.; Pan, L.; Thormann, U.; Schnettler, R.; Strauss, L.G.; Heinemann, S.; Schumacher, M.; Gelinsky, M.; Nies, B.; et al. Application of F-18-sodium fluoride (NaF) dynamic PET-CT (dPET-CT) for defect healing: A comparison of biomaterials in an experimental osteoporotic rat model. Med. Sci. Monit. 2014, 20, 1942-1949. [PubMed]

40. van Houdt, C.I.A.; Ulrich, D.J.O.; Jansen, J.A.; van den Beucken, J.J.J.P. The performance of CPC/PLGA and Bio-Oss ${ }^{\circledR}$ for bone regeneration in healthy and osteoporotic rats. J. Biomed. Mater. Res. B Appl. Biomater. 2018, 106, 131-142. [CrossRef]

41. Quan, H.; He, Y.; Sun, J.; Yang, W.; Luo, W.; Dou, C.; Kang, F.; Zhao, C.; He, J.; Yang, X.; et al. Chemical self-assembly of multifunctional hydroxyapatite with a coral-like nanostructure for osteoporotic bone reconstruction. ACS Appl. Mater. Interfaces 2018, 10, 25547-25560. [CrossRef] [PubMed]

42. Jeong, J.H.; Jin, E.S.; Kim, J.Y.; Lee, B.; Min, J.; Jeon, S.R.; Lee, M.; Choi, K.H. The effect of biocomposite screws on bone regeneration in a rat osteoporosis model. World Neurosurg. 2017, 106, 964-972. [CrossRef]

43. Clafshenkel, W.P.; Rutkowski, J.L.; Palchesko, R.N.; Romeo, J.D.; McGowan, K.A.; Gawalt, E.S.; Witt-Enderby, P.A. A novel calcium aluminate-melatonin scaffold enhances bone regeneration within a calvarial defect. J. Pineal Res. 2012, 53, 206-218. [CrossRef] [PubMed]

44. Li, L.; Peng, X.; Qin, Y.; Wang, R.; Tang, J.; Cui, X.; Wang, T.; Liu, W.; Pan, H.; Li, B. Acceleration of bone regeneration by activating $\mathrm{Wnt} / \beta$-catenin signalling pathway via lithium released from lithium chloride/calcium phosphate cement in osteoporosis. Sci. Rep. 2017, 7, 45204. [CrossRef] [PubMed]

45. Fang, W.; Zhao, S.; He, F.; Liu, L.; Yang, G. Influence of simvastatin-loaded implants on osseointegration in an ovariectomized animal model. BioMed Res. Int. 2015, 2015, 831504. [CrossRef]

46. Wu, Y.; Cao, L.; Xia, L.; Wu, Q.; Wang, J.; Wang, X.; Xu, L.; Zhou, Y.; Xu, Y.; Jiang, X. Evaluation of osteogenesis and angiogenesis of icariin in local controlled release and systemic delivery for calvarial defect in ovariectomized rats. Sci. Rep. 2017, 7, 5077. [CrossRef]

47. Xia, L.; Yin, Z.; Mao, L.; Wang, X.; Liu, J.; Jiang, X.; Zhang, Z.; Lin, K.; Chang, J.; Fang, B. Akermanite bioceramics promote osteogenesis, angiogenesis and suppress osteoclastogenesis for osteoporotic bone regeneration. Sci. Rep. 2016, 6, 22005. [CrossRef] [PubMed]

48. Liu, W.; Wang, T.; Yang, C.; Darvell, B.W.; Wu, J.; Lin, K.; Chang, J.; Pan, H.; Lu, W.W. Alkaline biodegradable implants for osteoporotic bone defects-importance of microenvironment pH. Osteoporos. Int. 2016, 27, $93-104$. [CrossRef]

49. Liu, X.; Bao, C.; Xu, H.H.K.; Pan, J.; Hu, J.; Wang, P.; Luo, E. Osteoprotegerin gene-modified BMSCs with hydroxyapatite scaffold for treating critical-sized mandibular defects in ovariectomized osteoporotic rats. Acta Biomater. 2016, 42, 378-388. [CrossRef]

50. Hauser, M.; Siegrist, M.; Denzer, A.; Saulacic, N.; Grosjean, J.; Bohner, M.; Hofstetter, W. Bisphosphonates reduce biomaterial turnover in healing of critical-size rat femoral defects. J. Orthop. Surg. (Hong Kong) 2018, 26, 2309499018802487. [CrossRef]

51. Gong, T.; Chen, Y.; Zhang, Y.; Zhang, Y.; Liu, X.; Troczynski, T.; Häfeli, U.O. Osteogenic and anti-osteoporotic effects of risedronate-added calcium phosphate silicate cement. Biomed. Mater. 2016, 11, 045002. [CrossRef]

52. Shen, X.; Ma, P.; Hu, Y.; Xu, G.; Xu, K.; Chen, W.; Ran, Q.; Dai, L.; Yu, Y.; Mu, C.; et al. Alendronate-loaded hydroxyapatite-TiO2 nanotubes for improved bone formation in osteoporotic rabbits. J. Mater. Chem. B 2016, 4, 1423-1436. [CrossRef]

53. Wu, C.C.; Kuo, C.L.; Fan, F.Y.; Yang, K.C. Strontium-impregnated bioabsorbable composite for osteoporotic fracture fixation. J. Biomed. Mater. Res. A 2015, 103, 3355-3363. [CrossRef]

54. Zarins, J.; Pilmane, M.; Sidhoma, E.; Salma, I.; Locs, J. Immunohistochemical evaluation after Sr-enriched biphasic ceramic implantation in rabbits femoral neck: Comparison of seven different bone conditions. J. Mater. Sci. Mater. Med. 2018, 29, 119. [CrossRef] [PubMed]

55. Yu, J.; Xu, L.; Li, K.; Xie, N.; Xi, Y.; Wang, Y.; Zheng, X.; Chen, X.; Wang, M.; Ye, X. Zinc-modified calcium silicate coatings promote osteogenic differentiation through TGF- $\beta /$ Smad pathway and osseointegration in osteopenic rabbits. Sci. Rep. 2017, 7, 3440. [CrossRef]

56. Lozano, D.; Trejo, C.G.; Gómez-Barrena, E.; Manzano, M.; Doadrio, J.C.; Salinas, A.J.; Vallet-Regí, M.; García-Honduvilla, N.; Esbrit, P.; Buján, J. Osteostatin-loaded onto mesoporous ceramics improves the early phase of bone regeneration in a rabbit osteopenia model. Acta Biomater. 2012, 8, 2317-2323. [CrossRef] [PubMed] 
57. Luo, E.; Hu, J.; Bao, C.; Li, Y.; Tu, Q.; Murray, D.; Chen, J. Sustained release of adiponectin improves osteogenesis around hydroxyapatite implants by suppressing osteoclast activity in ovariectomized rabbits. Acta Biomater. 2012, 8, 734-743. [CrossRef] [PubMed]

58. Plaza, J.Q.; Garzón, L.B.; Gimenez, B.B.; Moraleda, B.F.; Collía, F.; Rodríguez-Lorenzo, L.M. Application of calcium phosphates and fibronectin as complementary treatment for osteoporotic bone fractures. Injury 2016, 47, S15-S21. [CrossRef]

59. Gunnella, F.; Kunisch, E.; Maenz, S.; Horbert, V.; Xin, L.; Mika, J.; Borowski, J.; Bischoff, S.; Schubert, H.; Sachse, A.; et al. The GDF5 mutant BB-1 enhances the bone formation induced by an injectable, poly(l-lactide-co-glycolide) acid (PLGA) fiber-reinforced, brushite-forming cement in a sheep defect model of lumbar osteopenia. Spine J. 2018, 18, 357-369. [CrossRef]

60. Gunnella, F.; Kunisch, E.; Bungartz, M.; Maenz, S.; Horbert, V.; Xin, L.; Mika, J.; Borowski, J.; Bischoff, S.; Schubert, H.; et al. Low-dose BMP-2 is sufficient to enhance the bone formation induced by an injectable, PLGA fiber-reinforced, brushite-forming cement in a sheep defect model of lumbar osteopenia. Spine J. 2017, 17, 1699-1711. [CrossRef]

61. James, A.W.; Chiang, M.; Asatrian, G.; Shen, J.; Goyal, R.; Chung, C.G.; Chang, L.; Shrestha, S.; Turner, A.S.; Seim, H.B.; et al. Vertebral Implantation of NELL-1 Enhances Bone Formation in an Osteoporotic Sheep Model. Tissue Eng. Part A 2016, 22, 840-849. [CrossRef]

62. Verron, E.; Pissonnier, M.L.; Lesoeur, J.; Schnitzler, V.; Fellah, B.H.; Pascal-Moussellard, H.; Pilet, P.; Gauthier, O.; Bouler, J.M. Vertebroplasty using bisphosphonate-loaded calcium phosphate cement in a standardized vertebral body bone defect in an osteoporotic sheep model. Acta Biomater. 2014, 10, 4887-4895. [CrossRef] [PubMed]

63. Andreasen, C.M.; Ding, M.; Andersen, T.L.; Overgaard, S. Effects of substitute coated with hyaluronic acid or poly-lactic acid on implant fixation: Experimental study in ovariectomized and glucocorticoid-treated sheep. J. Tissue Eng. Regen. Med. 2018, 12, e1122-e1130. [CrossRef]

64. Izquierdo-Barba, I.; Santos-Ruiz, L.; Becerra, J.; Feito, M.J.; Fernández-Villa, D.; Serrano, M.C.; Díaz-Güemes, I.; Fernández-Tomé, B.; Enciso, S.; Sánchez-Margallo, F.M.; et al. Synergistic effect of Si-hydroxyapatite coating and VEGF adsorption on Ti6Al4V-ELI scaffolds for bone regeneration in an osteoporotic bone environment. Acta Biomater. 2019, 83, 456-466. [CrossRef]

65. Alt, V.; Cheung, W.H.; Chow, S.K.; Thormann, U.; Cheung, E.N.; Lips, K.S.; Schnettler, R.; Leung, K.S. Bone formation and degradation behavior of nanocrystalline hydroxyapatite with or without collagen-type 1 in osteoporotic bone defects-an experimental study in osteoporotic goats. Injury 2016, 47, S58-65. [CrossRef]

66. Chandran, S.; Shenoy, S.J.; Babu, S.S.; P Nair, R.; Varma, H.K.; John, A. Strontium hydroxyapatite scaffolds engineered with stem cells aid osteointegration and osteogenesis in osteoporotic sheep model. Colloids Surf B Biointerfaces 2018, 163, 346-354. [CrossRef]

67. Aro, H.T.; Alm, J.J.; Moritz, N.; Mäkinen, T.J.; Lankinen, P. Low BMD affects initial stability and delays stem osseointegration in cementless total hip arthroplasty in women: A 2-year RSA study of 39 patients. Acta Orthop. 2012, 83, 107-114. [CrossRef]

68. Lee, Y.K.; Ha, Y.C.; Chang, B.K.; Kim, K.C.; Kim, T.Y.; Koo, K.H. Cementless bipolar hemiarthroplasty using a hydroxyapatite-coated long stem for osteoporotic unstable intertrochanteric fractures. J. Arthroplast. 2011, 26, 626-632. [CrossRef]

69. Klein, R.; Tetzlaff, R.; Weiss, C.; Schäfer, M.K.; Tanner, M.; Wiedenhöfer, B.; Grafe, I.; Meeder, P.J.; Noeldge, G.; Nawroth, P.P.; et al. Osteointegration and resorption of intravertebral and extravertebral calcium phosphate cement. Clin. Spine Surg. 2017, 30, E291-E296. [CrossRef]

70. Jang, S.H.; Lee, J.H.; Cho, J.Y.; Lee, H.Y.; Lee, S.H. The efficacy of hydroxyapatite for screw augmentation in osteoporotic patients. Neurol. Med. Chir. (Tokyo) 2013, 53, 875-881. [CrossRef]

71. Shin, S.J.; Lee, J.H.; Lee, J.H. Influence of hydroxyapatite stick on pedicle screw fixation in degenerative lumbar spine: Biomechanical and radiologic study. Clin. Spine Surg. 2017, 30, E819-E826. [CrossRef]

72. Epidemiology. Available online: https://www.iofbonehealth.org/epidemiology (accessed on 11 March 2019).

73. Curtis, E.M.; Moon, R.J.; Harvey, N.C.; Cooper, C. The impact of fragility fracture and approaches to osteoporosis risk assessment worldwide. Bone 2017, 104, 29-38. [CrossRef]

74. Pesce, V.; Speciale, D.; Sammarco, G.; Patella, S.; Spinarelli, A.; Patella, V. Surgical approach to bone healing in osteoporosis. Clin. Cases Miner. Bone Metab. 2009, 6, 131-135. 
75. Barfeie, A.; Wilson, J.; Rees, J. Implant surface characteristics and their effect on osseointegration. Br. Dent. J. 2015, 218, E9. [CrossRef]

76. Ogle, O.E. Implant surface material, design and osseointegration. Dent. Clin. N. Am. 2015, 59, 505-520. [CrossRef] [PubMed]

77. Malard, O.; Bouler, J.M.; Guicheux, J.; Heymann, D.; Pilet, P.; Coquard, C.; Daculsi, G. Influence of biphasic calcium phosphate granulometry on bone ingrowth, ceramic resorption and inflammatory reactions: Preliminary in vitro and in vivo study. J. Biomed. Mater. Res. 1999, 46, 103-111. [CrossRef]

78. Lange, T.; Schilling, A.F.; Peters, F.; Mujas, J.; Wicklein, D.; Amling, M. Size dependent induction of proinflammatory cytokines and cytotoxicity of particulate beta-tricalciumphosphate in vitro. Biomaterials 2011, 32, 4067-4075. [CrossRef] [PubMed]

79. Laquerriere, P.; Grandjean-Laquerriere, A.; Guenounou, M.; Laurent-Maquin, D.; Frayssinet, P.; Nardin, M. Correlation between sintering temperature of hydroxyapatite particles and the production of inflammatory cytokines by human monocytes. Colloid Surf. B 2003, 30, 207-213. [CrossRef]

80. Boanini, E.; Torricelli, P.; Sima, F.; Axente, E.; Fini, M.; Mihailescu, I.N.; Bigi, A. Strontium and zoledronate hydroxyapatites graded composite coatings for bone prostheses. J. Colloid Interface Sci. 2015, 448. [CrossRef]

81. Panzavolta, S.; Torricelli, P.; Casolari, S.; Parrilli, A.; Fini, M.; Bigi, A. Strontium-substituted hydroxyapatite-gelatin biomimetic scaffolds modulate bone cell response. Macromol. Biosci. 2018, 18, e1800096. [CrossRef] [PubMed]

82. Boanini, E.; Torricelli, P.; Sima, F.; Axente, E.; Fini, M.; Mihailescu, I.N.; Bigi, A. Gradient coatings of strontium hydroxyapatite/zinc $\beta$-tricalcium phosphate as a tool to modulate osteoblast/osteoclast response. J. Inorg. Biochem. 2018, 183. [CrossRef]

83. Bracci, B.; Torricelli, P.; Panzavolta, S.; Boanini, E.; Giardino, R.; Bigi, A. Effect of $\operatorname{Mg}(2+), \operatorname{Sr}(2+)$ and $\mathrm{Mn}(2+)$ on the chemico-physical and in vitro biological properties of calcium phosphate biomimetic coatings. J. Inorg. Biochem. 2009, 103, 1666-1674. [CrossRef] [PubMed]

84. Bigi, A.; Boanini, E. Functionalized biomimetic calcium phosphates for bone tissue repair. J. Appl. Biomater. Funct. Mater. 2017, 15, e313-e325. [CrossRef]

85. Pan, J.; He, S.; Yin, X.; Li, Y.; Zhou, C.; Zou, S. Lithium enhances alveolar bone formation during orthodontic retention in rats. Orthod. Craniofac. Res. 2017, 20, 146-151. [CrossRef] [PubMed]

86. Salamanna, F.; Giavaresi, G.; Contartese, D.; Bigi, A.; Boanini, E.; Parrilli, A.; Lolli, R.; Gasbarrini, A.; Barbanti Brodano, G.; Fini, M. Effect of strontium substituted $\beta$-TCP associated to mesenchymal stem cells from bone marrow and adipose tissue on spinal fusion in healty and ovariectomized rat. J. Cell Physiol. 2019. [CrossRef]

87. Dolci, L.S.; Panzavolta, S.; Torricelli, P.; Albertini, B.; Sicuro, L.; Fini, M.; Bigi, A.; Passerini, N. Modulation of Alendronate release from a calcium phosphate bone cement: An in vitro osteoblast-osteoclast co-culture study. Int. J. Pharm. 2019, 554, 245-255. [CrossRef]

88. Forte, L.; Sarda, S.; Combes, C.; Brouillet, F.; Gazzano, M.; Marsan, O.; Boanini, E.; Bigi, A. Hydroxyapatite functionalization to trigger adsorption and release of risedronate. Colloids Surf. B Biointerfaces 2017, 160, 493-499. [CrossRef] [PubMed]

89. Panzavolta, S.; Torricelli, P.; Bracci, B.; Fini, M.; Bigi, A. Functionalization of biomimetic calcium phosphate bone cements with alendronate. J. Inorg. Biochem. 2010, 104, 1099-1106. [CrossRef]

90. Asaumi, K.; Nakanishi, T.; Asahara, H.; Inoue, H.; Takigawa, M. Expression of neurotrophins and their receptors (TRK) during fracture healing. Bone 2000, 26, 625-633. [CrossRef]

91. Shah, S.R.; Werlang, C.A.; Kasper, F.K.; Mikos, A.G. Novel applications of statins for bone regeneration. Natl. Sci. Rev. 2015, 2, 85-99. [CrossRef]

92. Liu, J.; Huang, F.; He, H.W. Melatonin effects on hard tissues: Bone and tooth. Int. J. Mol. Sci. 2013, 14, 10063-10074. [CrossRef]

93. Zhang, X.; Liu, T.; Huang, Y.; Wismeijer, D.; Liu, Y. Icariin: Does it have an osteoinductive potential for bone tissue engineering? Phytother. Res. 2014, 28, 498-509. [CrossRef]

94. Amengual-Peñafiel, L.; Brañes-Aroca, M.; Marchesani-Carrasco, F.; Jara-Sepúlveda, M.C.; Parada-Pozas, L.; Cartes-Velásquez, R. Coupling between osseointegration and mechanotransduction to maintain foreign body equilibrium in the long-term: A comprehensive overview. J. Clin. Med. 2019, 8, 139. [CrossRef] [PubMed]

95. Velard, F.; Braux, J.; Amedee, J.; Laquerriere, P. Inflammatory cell response to calcium phosphate biomaterial particles: An overview. Acta Biomater. 2013, 9, 4956-4963. [CrossRef] 
96. Macari, S.; Duffles, L.F.; Queiroz-Junior, C.M.; Madeira, M.F.M.; Dias, G.J.; Teixeira, M.M.; Szawka, R.E.; Silva, T.A. Oestrogen regulates bone resorption and cytokine production in the maxillae of female mice. Arch. Oral Biol. 2015, 60, 333-341. [CrossRef] [PubMed]

97. Rehman, D.; Qureshi, S.; Haq, A.A. Early detection of osteoporosis from incisure depth of human mandible in an orthopantomogram. J. Pak. Med. Assoc. 2014, 64, 766-769. [PubMed]

98. Scalize, P.H.; de Sousa, L.G.; Regalo, S.C.; Semprini, M.; Pitol, D.L.; da Silva, G.A.; de Almeida Coelho, J.; Coppi, A.A.; Laad, A.A.; Prado, K.F.; et al. Low-level laser therapy improves bone formation: Stereology findings for osteoporosis in rat model. Lasers Med. Sci. 2015, 30, 1599-1607. [CrossRef] [PubMed]

99. Hirata, H.H.; Munhoz, M.A.; Plepis, A.M.; Martins, V.C.; Santos, G.R.; Galdeano, E.A.; Cunha, M.R. Feasibility study of collagen membranes derived from bovine pericardium and intestinal serosa for the repair of cranial defects in ovariectomised rats. Injury 2015, 46, 1215-1222. [CrossRef] [PubMed]

(C) 2019 by the authors. Licensee MDPI, Basel, Switzerland. This article is an open access article distributed under the terms and conditions of the Creative Commons Attribution (CC BY) license (http://creativecommons.org/licenses/by/4.0/). 